\title{
Resistance to Phytophthora cinnamomi in American Chestnut (Castanea dentata) Backcross Populations that Descended from Two Chinese Chestnut (Castanea mollissima) Sources of Resistance
}

\author{
Jared W. Westbrook, ${ }^{1, \dagger}$ Joseph B. James, ${ }^{2}$ Paul H. Sisco, ${ }^{1}$ John Frampton, ${ }^{3}$ Sunny Lucas, ${ }^{4}$ and Steven N. Jeffers ${ }^{5, \dagger}$ \\ ${ }^{1}$ The American Chestnut Foundation, Asheville, NC 28804 \\ ${ }^{2}$ The American Chestnut Foundation and Chestnut Return Farms, Seneca, SC 29672 \\ ${ }^{3}$ Department of Forestry and Environmental Resources, North Carolina State University, Raleigh, NC 27695 \\ ${ }^{4}$ United States Department of Agriculture Forest Service Resistance Screening Center, Asheville, NC 28806 \\ ${ }^{5}$ Department of Plant and Environmental Sciences, Clemson University, Clemson, SC 29634
}

\begin{abstract}
Restoration of American chestnut (Castanea dentata) depends on combining resistance to both the chestnut blight fungus (Cryphonectria parasitica) and Phytophthora cinnamomi, which causes Phytophthora root rot, in a diverse population of $C$. dentata. Over a 14-year period (2004 to 2017), survival and root health of American chestnut backcross seedlings after inoculation with $P$. cinnamomi were compared among $28 \mathrm{BC}_{3}, 66 \mathrm{BC}_{4}$, and $389 \mathrm{BC}_{3} \mathrm{~F}_{3}$ families that descended from two $\mathrm{BC}_{1}$ trees (Clapper and Graves) with different Chinese chestnut grandparents. The 5\% most resistant Graves $\mathrm{BC}_{3} \mathrm{~F}_{3}$ families survived P. cinnamomi infection at rates of 75 to $100 \%$ but had mean root health scores that were intermediate between

chestnut blight canker severity. Only low to intermediate resistance to $P$. cinnamomi was detected among backcross descendants from the Clapper tree. Results suggest that major-effect resistance alleles were inherited by descendants from the Graves tree, that intercrossing backcross trees enhances progeny resistance to $P$. cinnamomi, and that alleles for resistance to $P$. cinnamomi and $C$. parasitica are not linked. To combine resistance to both C. parasitica and $P$. cinnamomi, a diverse Graves backcross population will be screened for resistance to $P$. cinnamomi, survivors bred with trees selected for resistance to $C$. parasitica, and progeny selected for resistance to both pathogens will be intercrossed.
\end{abstract} resistant Chinese chestnut and susceptible American chestnut families. Within Graves $\mathrm{BC}_{3} \mathrm{~F}_{3}$ families, seedling survival was greater than survival of Graves $\mathrm{BC}_{3}$ and $\mathrm{BC}_{4}$ families and was not genetically correlated with
Keywords: backcross breeding, chestnut blight, Cryphonectria parasitica, heritability, host resistance, ink disease, Phytophthora root rot.
Although the introduction of the fungus that causes chestnut blight (Cryphonectria parasitica (Murr.) Barr) in the early 20th century eventually caused the functional extinction of American chestnut trees (Castanea dentata (Marsh.) Borkh.) in the eastern United States, Phytophthora root rot, caused by the soilborne oomycete Phytophthora cinnamomi Rands (Crandall et al. 1945; Tucker 1933), is thought to have extirpated American chestnut trees from lower-elevation forests in the southeastern United States prior to the introduction of Cryphonectria parasitica (Anagnostakis 2012; Crandall et al. 1945; Freinkel 2007; Zentmyer 1980). A disease suspected to be Phytophthora root rot (also known as ink disease) was first reported in 1824 killing Allegheny chinquapin shrubs (Castanea pumila Mill.) in Georgia (Anagnostakis 2001, 2012), and American chestnut is also highly susceptible to P. cinnamomi (Crandall et al. 1945; Jeffers et al. 2009). Therefore, extensive mortality of American chestnut trees in the southeastern United States in the early to mid-1800s has been speculated to be from Phytophthora root rot (Crandall et al. 1945; Zentmyer 1980). Today, Phytophthora root rot has the potential to limit reintroduction of American chestnut trees with improved resistance to

${ }^{\dagger}$ Corresponding authors: J. W. Westbrook; E-mail: jared.westbrook@acf.org; and S. N. Jeffers; E-mail: sjffrs@ clemson.edu

Funding: This material is based on research that was supported by The American Chestnut Foundation and by the United States Department of Agriculture National Institute of Food and Agriculture, under project numbers SC1700309, SC-1700445, SC-1700481, and SC-1700534 at Clemson University. Technical Contribution No. 6715 of the Clemson University Experiment Station.

The author(s) declare no conflict of interest.

Accepted for publication 1 February 2019.

(c) 2019 The American Phytopathological Society
Cryphonectria parasitica across large areas of the native range of Castanea dentata (Anagnostakis 2001; Jacobs 2007). Whereas American chestnut resprouts from the roots after stems are killed by chestnut blight, the whole plant is killed by Phytophthora root rot

Until recently, Phytophthora root rot on American chestnut was reported to be caused only by P. cinnamomi (Crandall et al. 1945; Tucker 1933). The source, location, and timing of the earliest introduction of $P$. cinnamomi to the United States is not known but $P$. cinnamomi is speculated to have been imported into the southeastern United States on exotic plants from southeastern Asia, where $P$. cinnamomi is thought to have originated (Crandall and Gravatt 1967; Crandall et al. 1945; Zentmyer 1980, 1988). Currently, P. cinnamomi is the most common and virulent species of Phytophthora on American chestnut but $P$. cambivora (most likely $P$. $\times$ cambivora) (Jung et al. 2017), $P$. cryptogea, and $P$. heveae recently were isolated from American and backcross hybrid chestnut seedlings and have been found to cause lesions on roots of American chestnut seedlings after artificial inoculation (Sharpe 2017).

The chestnut blight fungus produces propagules that are both windborne and splash dispersed, and this pathogen is ubiquitous throughout the native range of American chestnut (Anagnostakis 2012; Freinkel 2007). By contrast, $P$. cinnamomi is a soilborne pathogen with a random distribution in time and space (Crandall et al. 1945; Meadows and Jeffers 2011). Soil moisture is essential for the production of sporangia and release of zoospores by $P$. cinnamomi (Zentmyer 1980). Phytophthora root rot on American chestnut seedlings was most damaging in moist soils in controlled experiments (Rhoades et al. 2003). $P$. cinnamomi spreads to host plants in water or soil containing infective propagules (i.e., motile zoospores or chlamydospores), by growth of plant roots into infested soil, or by root-to-root contact (Ristaino and Gumpertz 2000; Zentmyer 1980). The current geographic range of P. cinnamomi in the eastern United States overlaps with the range of American chestnut from Alabama to southern Pennsylvania. P. cinnamomi is not prevalent north of $40^{\circ} \mathrm{N}$ latitude at the present time, presumably due to the adverse effects of prolonged cold temperatures 
during winter (Balci et al. 2007; Benson 1982). However, as the climate warms, the range of $P$. cinnamomi is predicted to expand into the northeastern region of the United States by 2080 (Burgess et al. 2017).

Recent efforts to restore the American chestnut to its native range have focused on improving resistance to Cryphonectria parasitica in American chestnut populations (Anagnostakis 2012). Since 1983, The American Chestnut Foundation (TACF) has pursued backcross breeding to generate hybrids that combine resistance to $C$. parasitica from Chinese chestnut (Castanea mollissima Blume) with the timber-type form of American chestnut (Burnham et al. 1986). In a TACF breeding program, two sources of resistance to C. parasitica, which descended from two distinct $C$. mollissima trees, have been advanced to the third backcross generation $\left(\mathrm{BC}_{3}\right)$ with $C$. dentata. Two generations of intercrossing between backcross trees selected for resistance to $C$. parasitica have been performed to enhance this resistance in the $\mathrm{BC}_{3} \mathrm{~F}_{2}$ and $\mathrm{BC}_{3} \mathrm{~F}_{3}$ generations (Steiner et al. 2017).

Chinese chestnut also is resistant to P. cinnamomi (Crandall et al. 1945; Jeffers et al. 2009, 2012). Thus, American chestnut backcross descendants selected for resistance to $C$. parasitica potentially inherited alleles for $P$. cinnamomi resistance from $C$. mollissima. However, TACF has not selected for resistance to $P$. cinnamomi in backcross generations. Several coauthors of this study (i.e., S. N. Jeffers, J. B. James, and P. H. Sisco) began screening seedlings of American chestnut backcross families for resistance to $P$. cinnamomi in 2004 after $P$. cinnamomi had killed over $80 \%$ of $\mathrm{BC}_{2}$ American chestnut seedlings growing in a planting in Oconee County, SC between 2001 and 2003 (James 2011a,b; Laurie 2014). In annual trials conducted from 2004 to 2011, these collaborators evaluated seedling resistance to $P$. cinnamomi among American chestnut $\mathrm{BC}_{3}$ and $\mathrm{BC}_{4}$ progeny of $\mathrm{BC}_{2}$ and $\mathrm{BC}_{3}$ trees selected for resistance to $C$. parasitica (Jeffers et al. 2009, 2012). In 2012, this group began screening seedlings in $\mathrm{BC}_{3} \mathrm{~F}_{3}$ families that were derived from open pollination among $\mathrm{BC}_{3} \mathrm{~F}_{2}$ trees. TACF collaborated with J. Frampton (another coauthor) at North Carolina State University (NCSU) to evaluate additional $\mathrm{BC}_{3} \mathrm{~F}_{3}$ families from 2014 to 2016. Beginning in 2017, evaluation of seedlings in $\mathrm{BC}_{3} \mathrm{~F}_{3}$ families was conducted by TACF in collaboration with personnel at the United States Department of Agriculture (USDA) Forest Service Resistance Screening Center in Asheville, NC.

The overall objective of this project was to evaluate first-year hybrid American chestnut seedlings for resistance to P. cinnamomi under standardized conditions. If resistance was identified, a secondary objective was to identify the source or sources of the resistance. We present results of evaluating seedlings of American chestnut, Chinese chestnut, and American chestnut backcross progeny for resistance to $P$. cinnamomi over 14 growing seasons (2004 to 2017). Genetic variation in resistance to $P$. cinnamomi was estimated among three generations of American chestnut backcross families $\left(\mathrm{BC}_{3}, \mathrm{BC}_{4}\right.$, and $\mathrm{BC}_{3} \mathrm{~F}_{3}$ ) that descended from two $\mathrm{BC}_{1}$ trees. This dataset enabled us to test for loss of $P$. cinnamomi resistance with successive backcrosses to $C$. dentata and for increases in resistance through intercrossing backcross trees. Among $\mathrm{BC}_{3} \mathrm{~F}_{3}$ families, $P$. cinnamomi resistance was compared for a subset of families screened at multiple locations using different isolates of $P$. cinnamomi and different procedures for disease phenotyping. A genetic correlation between resistance to $P$. cinnamomi and $C$. parasitica was estimated among American chestnut $\mathrm{BC}_{3} \mathrm{~F}_{3}$ families that were screened for resistance to both pathogens. Implications for breeding to combine resistance to $P$. cinnamomi and C. parasitica are discussed.

\section{Materials and Methods}

Sources of seed and research trial locations. The American chestnut backcross seedlings evaluated for resistance to $P$. cinnamomi were descendants of the Clapper and Graves sources of resistance to $C$. parasitica. Clapper and Graves are two $\mathrm{BC}_{1}$ trees $((C$. mollissima $\times C$. dentata $) \times C$. dentata) with different $C$. mollissima grandparents (Anagnostakis 2007; Clapper 1952; Hebard 2006). A subset of $\mathrm{BC}_{2}$ and $\mathrm{BC}_{3}$ descendants of Clapper and Graves, which were selected for resistance to $C$. parasitica at
TACF Meadowview Research Farms, were crossed with susceptible $C$. dentata parents to generate $\mathrm{BC}_{3}$ and $\mathrm{BC}_{4}$ progeny that were evaluated for resistance to $P$. cinnamomi. In total, progeny of 10 of 41 Clapper $\mathrm{BC}_{2}$ selections, 20 of 83 Clapper $\mathrm{BC}_{3}$ selections, 18 of 41 Graves $\mathrm{BC}_{2}$ selections, and 46 of 71 Graves $\mathrm{BC}_{3}$ selections were evaluated for resistance to $P$. cinnamomi.

The $\mathrm{BC}_{3} \mathrm{~F}_{3}$ seed were obtained from TACF Meadowview Research Farms through open pollination of 124 Clapper and 265 Graves $\mathrm{BC}_{3} \mathrm{~F}_{2}$ mothers by neighboring $\mathrm{BC}_{3} \mathrm{~F}_{2}$ trees. Similarly, the $\mathrm{BC}_{3} \mathrm{~F}_{2}$ parents were generated through open pollination among $\mathrm{BC}_{3}$ trees. To put the number of $\mathrm{BC}_{3} \mathrm{~F}_{3}$ families that were evaluated for $P$. cinnamomi resistance into context, approximately 36,000 $\mathrm{BC}_{3} \mathrm{~F}_{2}$ progeny of 83 Clapper $\mathrm{BC}_{3}$ trees and $27,000 \mathrm{BC}_{3} \mathrm{~F}_{2}$ progeny of 71 Graves $\mathrm{BC}_{3}$ trees have been planted in Meadowview seed orchards since 2002. These approximately $63,000 \mathrm{BC}_{3} \mathrm{~F}_{2}$ trees were artificially inoculated with $C$. parasitica, and the most susceptible trees were culled based on severity of blight canker development (Steiner et al. 2017). At the time of the writing of this article, approximately 5,000 Clapper $\mathrm{BC}_{3} \mathrm{~F}_{2}$ trees and 4,250 Graves $\mathrm{BC}_{3} \mathrm{~F}_{2}$ trees remained in Meadowview seed orchards. The final objective is to cull all but $1 \%$ of trees that are most resistant to C. parasitica or P. cinnamomi (i.e., retain approximately 600 trees). Although we have evaluated a small subset of the total number of potential $\mathrm{BC}_{3} \mathrm{~F}_{3}$ families for $P$. cinnamomi resistance, we have likely screened $\mathrm{BC}_{3} \mathrm{~F}_{3}$ grand-progeny from a majority of the $\mathrm{BC}_{3}$ trees selected for blight resistance. The $\mathrm{BC}_{3} \mathrm{~F}_{2}$ mothers whose progeny were screened for resistance to $P$. cinnamomi were themselves the progeny of 41 of 71 Graves $\mathrm{BC}_{3}$ selections and 34 of 83 Clapper $\mathrm{BC}_{3}$ selections. It is likely that grand-progeny of additional $\mathrm{BC}_{3}$ selections have been represented in the screening through the unknown paternal contribution in the $\mathrm{BC}_{3} \mathrm{~F}_{2}$ and $\mathrm{BC}_{3} \mathrm{~F}_{3}$ generations. In this article, seedlings derived from open pollination of a given mother tree or from a specific controlled pollination are referred to as a family. Seed were collected in the fall and stratified in moist peat in plastic bags over the winter at 4 to $8^{\circ} \mathrm{C}$.

Chestnut seedlings were evaluated for resistance to $P$. cinnamomi at three locations: Clemson University personnel conducted trials in collaboration with colleagues at Chestnut Return Farms (Oconee County, SC); NCSU personnel conducted trials on the main campus in Raleigh, NC; and TACF personnel conducted trials in collaboration with colleagues at the USDA Forest Service Resistance Screening Center (Asheville, NC). At each location, different inoculation and phenotyping methods were used (detailed below) to insure that results were not artifacts of a single location, inoculation procedure, or evaluation method. To compare family rankings for $P$. cinnamomi resistance between pairs of locations and methods, subsets of 53 $\mathrm{BC}_{3} \mathrm{~F}_{3}$ families were evaluated by Clemson University and NCSU in 2014, 2015, and 2016. Another $17 \mathrm{BC}_{3} \mathrm{~F}_{3}$ families were evaluated by Clemson University and TACF with the USDA Forest Service in 2017. In each year and at each location, resistant Chinese chestnut and susceptible American chestnut seedlings were included as controls.

Trials conducted by Clemson University at Chestnut Return Farms: 2004 to 2017. The 14 annual trials conducted at Chestnut Return Farms have been summarized, including dates of planting, inoculation, and evaluation of Phytophthora root rot phenotypes; lengths of time between when seedlings were planted, inoculated, and evaluated; and numbers of seedlings and families evaluated (Table 1). Among 505 American chestnut backcross families evaluated during this time, 62 were descendants of Clapper and 166 were descendants of Graves. Detailed analyses of resistance to $P$. cinna$m o m i$ within hybrid and backcross families that descended from additional Chinese chestnut and Japanese chestnut trees, which were included in these trials, are beyond the scope of this article. Preliminary results of $P$. cinnamomi resistance in hybrid and backcross American chestnut seedlings, including those that descended from sources of resistance other than Clapper or Graves, have been reported (Jeffers et al. 2009, 2012).

Seed were sowed outdoors in early to mid-April (plus late March 2008) in 568-liter tubs (Structural Foam Stock Tank FG424500BLA: 
$147 \mathrm{~cm}$ long by $99 \mathrm{~cm}$ wide by $64 \mathrm{~cm}$ tall; Rubbermaid Commercial Products, High Point, NC) when radicles had emerged from approximately $50 \%$ of the seed. The tubs contained a soilless growing mix composed primarily of peat and bark (Fafard 3B Mix; currently produced by Sun Gro Horticulture, Agawam, MA). A subset of seed from each family was planted in 3 to 10 tubs. Between 1 and 25 seeds from each family (mean $=6$ ) were planted in each tub, depending on the year. Seed from individual families were planted together in a row, with approximately 1 to $3 \mathrm{~cm}$ between seeds and at a depth of 2 to $4 \mathrm{~cm}$. The position of families within tubs was randomized among tubs. Tubs were watered as needed throughout the growing season. Once seedlings had emerged, slow-release fertilizer (Osmocote; The Scotts Company, Marysville, $\mathrm{OH}$ ) was added to each tub in late April or early May.

Seedlings were inoculated with a combination of two isolates of $P$. cinnamomi (JJ-1 and JJ-52, both mating type A2) that were isolated in 2003 from backcross chestnut seedlings with Phytophthora root rot growing at Chestnut Return Farms. These isolates are stored in a permanent collection that is maintained by $\mathrm{S}$. N. Jeffers at Clemson University. The two isolates were grown independently on sterile rice grains (Holmes and Benson 1994; Meadows et al. 2011) in 2004 to 2007 and then on sterile vermiculite moistened with V8 juice broth (Roiger and Jeffers 1991) from 2007 to 2017. Both types of inoculum were used in 2007. Equal volumes of inoculum containing each isolate were thoroughly mixed before inoculation. Seedlings were inoculated 12 to 16 weeks after planting, usually in early to mid-July (Table 1). To inoculate, furrows (2 to $3 \mathrm{~cm}$ deep and 95 to $97 \mathrm{~cm}$ long) were made between every other row of seedlings, and inoculum (i.e., $10 \mathrm{ml}$ of rice or $50 \mathrm{ml}$ of V8-vermiculite) was sprinkled in the furrow, evenly distributed, and covered. After inoculation, seedlings in all tubs were watered to incorporate the inoculum and prevent it from desiccating. Tubs were flooded each year for a 6- to 8-h period one to three times in July or August to enhance disease development. At 20 to 29 weeks (mean $=24$ weeks) after inoculation, dormant seedlings were evaluated for disease severity (Table 1). Each seedling was removed carefully from a tub to keep the roots intact and washed in tap water. On each seedling, the roots and the lower stem were inspected for typical symptoms of Phytophthora root rot. Disease severity was scored on a 0 -to- 3 scale, where $0=$ no lesions on roots, plant healthy; 1 = lesions on some lateral roots or plant stunted; $2=$ lesions on the tap root or severe root rot on lateral roots; and $3=$ $100 \%$ root rot, plant dead (Jeffers et al. 2009).

Each year, one to three diseased seedlings and approximately 1 liter of container mix from each tub were collected and taken to the lab to confirm the presence of $P$. cinnamomi. Root systems were washed again under running tap water and blotted dry. Tissue pieces from advancing lesions were embedded in PARPH-V8 selective medium, and isolation plates were placed at $20^{\circ} \mathrm{C}$ for 5 to 7 days (Ferguson and Jeffers 1999; Jeffers 2015). Subsamples of container mix from each tub were assayed with a baiting bioassay using camellia and rhododendron leaf pieces as baits (Ferguson and Jeffers 1999; Meadows et al. 2011).

Trials conducted by NCSU: 2014 to 2016. During April and May of each year, 20 stratified seeds from each American chestnut, Chinese chestnut, and American chestnut backcross family were sowed individually into D40 Deepots $(650 \mathrm{ml}, 25 \times 6 \mathrm{~cm}$; Stuewe \& Sons, Tangent, OR) containing a 1:1 peat-perlite medium (Table 2). After initial growth at TACF Meadowview Research Farms in Virginia, seedlings were transferred to the Horticultural Field Lab at NCSU in Raleigh, NC on 24 June 2014, 22 May 2015, and 10 June 2016. Seedlings were grown outdoors under $40 \%$ shade cloth in a completely randomized design and were inoculated 7 to 10 weeks after planting by inserting three infested rice grains about $2.5 \mathrm{~cm}$ deep into separate holes in the medium of each Deepot and covering the grains. The rice grains had been colonized by a single isolate of $P$. cinnamomi (23ss04) obtained from a Fraser fir tree (Abies fraseri (Pursh) Poir.) in North Carolina with Phytophthora root rot (Frampton et al. 2013). Eight weeks after inoculation, surviving seedlings were reinoculated with the same isolate of $P$. cinnamomi to ensure that they had been challenged sufficiently by the pathogen. To promote disease development, seedlings were irrigated from above three times daily for $20 \mathrm{~min}$ (approximately $1.5 \mathrm{~cm} /$ day). Seedlings were fertilized periodically with 15-16-17 (N-P-K) Peters Peat-lite Special containing micronutrients (The Scotts Company) in an aqueous solution

Table 1. Summary of 14 consecutive annual trials to evaluate seedlings of American, Chinese, and backcross chestnut families for resistance to Phytophthora cinnamomi at Chestnut Return Farm in Oconee County, SS based on the percentage of seedlings surviving at the end of each trial

\begin{tabular}{|c|c|c|c|c|c|c|c|c|c|c|c|c|c|c|}
\hline \multirow[b]{2}{*}{ Year } & \multicolumn{3}{|c|}{ Dates on which seedlings were ${ }^{a}$} & \multicolumn{3}{|c|}{$\begin{array}{l}\text { Durations } \\
\text { (weeks) }\end{array}$} & \multicolumn{2}{|c|}{ Number of ${ }^{c}$} & \multicolumn{4}{|c|}{ Number of families ${ }^{d}$} & \multicolumn{2}{|c|}{$\begin{array}{c}\text { One-way ANOVA: } \\
P>F \text { values }\end{array}$} \\
\hline & Planted & Inoculated & Evaluated & P-I & I-E & P-E & Tubs & Seeds & BC & Am & $\mathbf{C h}$ & Total & Am vs. $\mathbf{C h}^{\mathrm{f}}$ & BC families ${ }^{\mathrm{g}}$ \\
\hline 2004 & 14 Apr 04 & $08 \mathrm{Jul} 04$ & 12 Jan 05 & 12 & 27 & 39 & 2 & 508 & 6 & 1 & 2 & 9 & $\mathrm{NC}$ & $\mathrm{NC}$ \\
\hline 2005 & 05 Apr 05 & 28 Jun 05 & 20 Dec 05 & 12 & 25 & 37 & 6 & 1,250 & 26 & 1 & 1 & 28 & $<0.001$ & $<0.001$ \\
\hline 2006 & 05 Apr 06 & 14 Jul 06 & 13 Dec 06 & 14 & 22 & 36 & 6 & 1,031 & 23 & 1 & 3 & 27 & $\mathrm{NC}$ & $<0.001$ \\
\hline 2007 & 04 Apr 07 & 19 Jul 07 & $18 \operatorname{Dec} 07$ & 15 & 22 & 37 & 7 & 1,545 & 42 & 5 & 1 & 48 & $<0.001$ & $<0.001$ \\
\hline 2008 & 27 Mar 08 & 14 Jul 08 & 17 Dec 08 & 16 & 22 & 38 & 7 & 1,279 & 23 & 4 & 1 & 28 & $<0.001$ & $<0.001$ \\
\hline 2009 & 08 Apr 09 & 09 Jul 09 & 28 Jan 10 & 13 & 29 & 42 & 7 & 1,020 & 32 & 3 & 2 & 37 & $<0.001$ & $<0.001$ \\
\hline 2010 & 09 Apr 10 & 22 Jul 10 & 07 Dec 10 & 15 & 20 & 35 & 9 & 1,502 & 54 & 1 & 1 & 56 & $<0.001$ & $<0.001$ \\
\hline 2011 & 05 Apr 11 & $11 \mathrm{Jul} 11$ & $13 \operatorname{Dec} 11$ & 14 & 22 & 36 & 10 & 1,633 & 48 & 1 & 1 & 50 & $<0.001$ & $<0.001$ \\
\hline 2012 & 02 Apr 12 & 12 Jul 12 & 09 Jan 13 & 14 & 26 & 40 & 13 & 1,914 & 76 & 3 & 1 & 80 & $<0.001$ & $<0.001$ \\
\hline 2013 & 17 Apr 13 & 30 Jul 13 & 18 Dec 13 & 15 & 20 & 35 & 11 & 1,480 & 71 & 1 & 1 & 73 & $<0.001$ & $<0.001$ \\
\hline 2014 & 02 Apr 14 & 10 Jul 14 & 09 Dec 14 & 14 & 22 & 36 & 13 & 1,869 & 32 & 1 & 1 & 34 & $<0.001$ & $<0.001$ \\
\hline 2015 & 08 Apr 15 & 07 Jul 15 & 13 Jan 16 & 13 & 27 & 40 & 13 & 1,639 & 29 & 1 & 1 & 31 & $<0.001$ & $<0.001$ \\
\hline 2016 & 06 Apr 16 & 06 Jul 16 & 12 Jan 17 & 13 & 27 & 40 & 11 & 1,210 & 23 & 1 & 1 & 25 & $<0.001$ & $<0.001$ \\
\hline 2017 & 13 Apr 17 & 06 Jul 17 & 23 Jan 18 & 12 & 29 & 41 & 5 & 645 & 20 & 1 & 1 & 22 & $<0.001$ & $<0.001$ \\
\hline Total & $\ldots$ & $\ldots$ & $\ldots$ & $\ldots$ & $\ldots$ & $\ldots$ & $\ldots$ & 18,525 & 505 & 25 & 18 & 548 & $\ldots$ & $\ldots$ \\
\hline
\end{tabular}

a Abbreviations: April (Apr), July (Jul), January (Jan), Jun (June), December (Dec), and March (Mar) in years 2004 (04) through 2018 (18).

${ }^{\mathrm{b}}$ Lengths of time in weeks between activities involving seedlings: $\mathrm{P}=$ planted, $\mathrm{I}=$ inoculated, and $\mathrm{E}=$ evaluated.

${ }^{\mathrm{c}}$ Number of 568 -liter tubs planted with seedlings and numbers of seeds planted each year.

${ }^{\mathrm{d}}$ Numbers of different families planted each year. A family is a specific chestnut genotype: $\mathrm{Am}=$ open-pollinated American chestnut, $\mathrm{Ch}=$ open-pollinated Chinese chestnut, and $\mathrm{BC}=$ open-pollinated and specific crosses of (American chestnut $\times$ Chinese chestnut) $\times$ American chestnut backcross hybrids .

e Results from statistical analyses by one-way analysis of variance (ANOVA): $P>F$ is the probability of a greater $F$ statistic occurring. Analyses were not conducted for some data (NC) because of insufficient replication.

${ }^{\mathrm{f}}$ Results showing the significant difference in survival between the American and Chinese chestnut families each year based on a single-degree-of-freedom linear contrast.

${ }^{g}$ Results showing the significant difference in survival among only the hybrid chestnut families evaluated each year based on a one-way ANOVA of a subset of the data from this trial. 
prepared to deliver $\mathrm{N}$ at $200 \mathrm{ppm}$. Symptom development was visually assessed 8 and 16 weeks after inoculation in 2014 and biweekly for 16 weeks in 2015 and 2016. Foliage health was assessed by estimating percent shoot (leaf and stem) necrosis on a 0-to-100 scale in increments of 10 but also including 1, 2, and 95\% levels. Seedlings were considered dead if $100 \%$ of the shoot was necrotic and alive (i.e., surviving) if otherwise. Each year, a control group of seedlings from each Chinese chestnut, American chestnut, and $\mathrm{BC}_{3} \mathrm{~F}_{3}$ family was not inoculated with $P$. cinnamomi and served as controls to estimate mortality rates in the absence of Phytophthora root rot.

Trial conducted by TACF and the USDA Forest Service in 2017. Forty seeds from each American chestnut, Chinese chestnut, and American chestnut backcross family were sowed in Fafard 3B Mix in D40 Deepots in a greenhouse at the USDA Forest Service Resistance Screening Center in February (Table 2). The pots were arranged in 20-cell trays in a randomized complete block design. The blocks consisted of 10 trays placed in flood tables that measured 1.2 by 1.8 by $0.3 \mathrm{~m}$. Once seedlings emerged, they were fertilized with time-release Osmocote fertilizer and irrigated overhead three times per week for 13 weeks prior to inoculation. After inoculation, seedlings were subirrigated three times each week for the duration of the trial. Subirrigation completely saturated the container mix in each Deepot and provided conducive conditions for disease development. Irrigation water was pumped from the flood tables to holding tanks and treated with bleach $(\mathrm{NaOCl})$ after use to prevent contaminating the site with $P$. cinnamomi. Seedlings were inoculated once with the same isolate of $P$. cinnamomi (23ss04) used in the NCSU trials, and the inoculum was prepared as colonized V8-vermiculite, as in the Clemson University trials. A 5-ml aliquot of V8-vermiculite inoculum was placed in each pot, the inoculum was covered immediately with sand, and the pots were watered to prevent desiccation of the inoculum. Survival was assessed by visual observation of foliage symptoms and removing seedlings with wilted crowns at 4, 8, 16, and 24 weeks after inoculation. Seedlings with wilted crowns were scored as dead, and roots on these seedlings were inspected for typical symptoms of Phytophthora root rot.

Evaluation of resistance to $\boldsymbol{C}$. parasitica. In total, 103 Graves $\mathrm{BC}_{3} \mathrm{~F}_{3}$ families that were evaluated for resistance to $P$. cinnamomi were also evaluated for resistance to $C$. parasitica at TACF Meadowview Research Farms. These 103 families were a subset of 544 families that had been evaluated for resistance to $C$. parasitica from 2011 to 2016 in separate experiments (Steiner et al. 2017). Thirty $\mathrm{BC}_{3} \mathrm{~F}_{3}$ seeds per family were planted in the field at Meadowview Research
Farms at 1-by-2.3-m spacing in a randomized complete block design (2011 to 2013) or resolvable incomplete design (2014 to 2016). Progeny from each family was inoculated in the third growing season with two isolates of $C$. parasitica: SG2-3 with low virulence and Ep155 with high virulence. Cankers lengths and subjective canker severity ratings $(1=$ no canker expansion, $2=$ some expansion beyond initial lesion, and $3=$ large, sunken canker with sporulation) were assessed 6 months after inoculation. Canker severity was estimated from the sum of the normalized canker length and canker severity rating for the two isolates of $C$. parasitica (Steiner et al. 2017).

Data analysis. The original root rot severity scores of 0 to 3 used in the Clemson University trials were reversed to root health scores of 3 to 0 , so that families could be ranked for resistance to $P$. cinnamomi. Seedlings scored as 3, 2, and 1 were alive while those scored as 0 were dead. An analysis of variance to detect differences in survival among families in each year and at each location was performed with the R package 'easyanova' (Arnhold 2013). Tubs were treated as complete blocks in analysis of survival in trials conducted by Clemson University and by TACF and the USDA Forest Service, whereas results from the trials conducted by NCSU were analyzed as a completely randomized design. Family means were judged significantly different if $P$ values from $F$ tests of family effects were less than 0.05 .

Mixed-model analyses of Phytophthora root rot phenotypes were performed in ASReml-R (Butler et al. 2009). Phenotypes of backcross descendants of the Clapper and Graves trees were analyzed separately. Root health rating (3-to-0 scale) or survival $(0,1)$ of seedlings in the Clemson University trials were analyzed using univariate models that included the population mean and the random effects of inoculation year, tub, family, and error. Crown health (0 to 100$)$ or survival $(0,1)$ of seedlings in the NCSU trials were analyzed employing univariate models that included the population mean and the random effects of inoculation year, family, and error. Seedling survival in the TACF-USDA Forest Service trial was analyzed in a model that included the population mean and the random effects of block, family, and error.

The heritability of Phytophthora root rot phenotypes was estimated for individual $\mathrm{BC}_{3} \mathrm{~F}_{3}$ trees with the formula:

$$
\mathrm{h}^{2}=4 \sigma_{\text {family }}^{2} / \sigma_{\text {phenotype }}^{2}
$$

where $\sigma_{\text {phenotype }}^{2}$ is the sum of the variance components associated with random effects in the model (i.e., year, family, block, and error).

Table 2. Summary of four annual trials to evaluate seedlings of American, Chinese, and $\mathrm{BC}_{3} \mathrm{~F}_{3}$ families for resistance to Phytophthora cinnamomi at North Carolina State University (NCSU) and the USDA Forest Service Resistance Screening Center (RSC) in Asheville, NC based on the percentage of seedlings surviving at the end of each trial

\begin{tabular}{|c|c|c|c|c|c|c|c|c|c|c|c|c|c|c|c|c|c|}
\hline \multirow[b]{2}{*}{ Trial $^{\mathrm{e}}$} & \multirow[b]{2}{*}{ Year } & \multicolumn{3}{|c|}{ Dates on which seedlings were ${ }^{a}$} & \multicolumn{3}{|c|}{$\begin{array}{c}\text { Duration } \\
\text { (weeks) }^{\mathbf{b}}\end{array}$} & \multicolumn{4}{|c|}{ Number of families ${ }^{c}$} & \multicolumn{4}{|c|}{ Number of seedlings } & \multicolumn{2}{|c|}{$\begin{array}{c}\text { One-way ANOVA: } \\
P>F \text { values }^{d}\end{array}$} \\
\hline & & Planted & Inoculated & $\overline{\text { Evaluated }}$ & $\overline{\text { P-I }}$ & I-E & $\overline{\text { P-E }}$ & $\overline{B C}$ & Am & Ch & $\overline{\text { Total }}$ & BC & Am & Ch & $\overline{\text { Total }}$ & Am vs. $\mathbf{C h}^{\mathbf{f}}$ & $\overline{\mathrm{BC}_{3} \mathrm{~F}_{3} \mathrm{~g}}$ \\
\hline$\overline{\mathrm{NCSU}}$ & 2014 & 15 May 14 & $23 \mathrm{Jul} 14$ & 12 Nov 14 & 10 & 16 & 26 & 95 & 0 & 0 & 95 & 2,259 & 0 & 0 & 2,259 & $\mathrm{NC}$ & $<0.001$ \\
\hline NCSU & 2015 & 01 Apr 15 & 29 May 15 & 18 Sep 15 & 8 & 16 & 24 & 97 & 2 & 2 & 101 & 1,892 & 40 & 32 & 1,964 & $<0.001$ & $<0.001$ \\
\hline NCSU & 2016 & 11 May 16 & 01 Jul 16 & 21 Oct 16 & 7 & 16 & 23 & 74 & 3 & 1 & 78 & 1,482 & 40 & 20 & 1,542 & $<0.001$ & $<0.001$ \\
\hline RSC & 2017 & 15 Feb 17 & 23 May 17 & 07 Nov 17 & 14 & 24 & 38 & 37 & 1 & 1 & 39 & 1,036 & 27 & 39 & 1,102 & $<0.001$ & $<0.001$ \\
\hline Total & 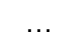 & 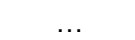 & & $\ldots$ & $\ldots$ & $\ldots$ & $\ldots$ & 287 & 6 & 4 & $297^{\mathrm{h}}$ & 6,669 & 107 & 91 & 6,897 & $\ldots$ & \\
\hline
\end{tabular}

a Abbreviations: July (Jul), November (Nov), April (Apr), September (Sep), October (Oct), and February (Feb) in years 2014 (14) through 2017 (17).

${ }^{\mathrm{b}}$ Lengths of time in weeks between activities involving seedlings: $\mathrm{P}=$ planted, $\mathrm{I}=$ inoculated, and $\mathrm{E}=$ evaluated.

${ }^{\mathrm{c}}$ Numbers of different families planted each year. A family is a specific chestnut genotype: $\mathrm{Am}=$ open-pollinated American chestnut, $\mathrm{Ch}=\mathrm{open}$-pollinated Chinese chestnut, and $\mathrm{BC}=$ specific $\mathrm{BC}_{3} \mathrm{~F}_{3}$ generation of American chestnut backcross hybrids.

${ }^{\mathrm{d}}$ Results from statistical analyses by one-way analysis of variance (ANOVA): $P>F$ is the probability of a greater $F$ statistic occurring. Analyses were not conducted for some data (NC) because of insufficient replication.

e NCSU = North Carolina State University and RSC $=$ The American Chestnut Foundation-United States Department of Agriculture Forest Service Resistance Screening Center.

${ }^{\mathrm{f}}$ Results showing the significant difference in survival between the American and Chinese chestnut families each year based on a single-degree-of-freedom linear contrast.

$\mathrm{g}$ Results showing the significant difference in survival among only the American chestnut $\mathrm{BC}_{3} \mathrm{~F}_{3}$ families evaluated each year based on a one-way ANOVA of a subset of the data from this trial.

${ }^{\mathrm{h}}$ Note that 16 families were each evaluated in two separate years; therefore, the sum of the number of families evaluated in all years (313) is greater than the total number of families evaluated (297) 
This heritability estimate assumes random mating among $\mathrm{BC}_{3} \mathrm{~F}_{2}$ trees and that $\mathrm{BC}_{3} \mathrm{~F}_{3}$ progeny were half-siblings (Lynch and Walsh 1998). The family variance component and best linear unbiased predictions (BLUPs) of Phytophthora root rot phenotypes for each family were estimated by incorporating the inverse of the pedigree-derived additive genetic relationship matrix into the model (Butler et al. 2009). The BLUPs were scaled from 0 (American chestnut mean) to 100 (Chinese chestnut mean) with the formula:

$$
\text { Scaled BLUP } \left.=100\left[1-\left(\mathrm{BLUP}-\mu_{\mathrm{Chin}}\right) / \mu_{\mathrm{Am}}-\mu_{\mathrm{Chin}}\right)\right]
$$

where BLUP is in the original scale and $\mu_{\mathrm{Chin}}$ and $\mu_{\mathrm{Am}}$ are the average BLUPs for Chinese chestnut and American chestnut families, respectively.

Bivariate analyses were performed to estimate genetic correlations between different Phytophthora root rot phenotypes from the same trees, survival of the same families inoculated with $P$. cinnamomi at different screening locations, and between Phytophthora root rot survival and chestnut blight canker severity. Covariance was estimated among all random effects (i.e., family, tub, and error) for analyses involving different phenotypes from the same trees. For bivariate analyses of Phytophthora root rot survival at different sites or between Phytophthora root rot survival and chestnut blight canker severity, experimental design effects and residuals were assumed to be uncorrelated while genetic covariance was estimated among families. Genetic correlations were estimated with the formula:

$$
\operatorname{Cov}_{\text {trait1,trait2 }} /\left[\sqrt{\operatorname{Var}_{\text {trait1 }}}+\sqrt{\operatorname{Var}_{\text {trait2 }}}\right]
$$

where Cov and Var are family covariance and variance components, respectively. Standard errors for genetic correlations and heritabilities were estimated with the $\Delta$ method (Lynch and Walsh 1998). Genetic correlations were considered significantly different than zero if the $P$ value from the likelihood ratio test of the correlation was less than 0.05 (Butler et al. 2009). Figures were prepared using the R package 'ggplot2' (Wickham 2009).

\section{Results}

Seedling survival within families after inoculation with $\boldsymbol{P}$. cinnamomi. Significant differences in seedling survival ( $F$ test, $P<0.001)$ were observed between resistant Chinese chestnut and susceptible American chestnut controls and among backcross families in all years and at all screening locations (Tables 1 and 2). In all, $11 \%$ of American chestnut seedlings inoculated with P. cinnamomi survived to the end of assessment periods - which, on average, was 38 weeks at Chestnut Return Farms, 24 weeks at the Resistance Screening Center, and 16 weeks at NCSU. In contrast, $97 \%$ of the Chinese chestnut seedlings survived over the same time period. In 111 Graves $\mathrm{BC}_{3} \mathrm{~F}_{3}$ families evaluated in the Clemson University trials, an average of $32 \%$ of the seedlings survived, whereas 75 to $100 \%$ of the seedlings survived in the 5\% most resistant families. Similar rates of survival were observed for seedlings in 156 Graves $\mathrm{BC}_{3} \mathrm{~F}_{3}$ families evaluated in NCSU trials, where seedling survival averaged
$24 \%$ overall, and 75 to $95 \%$ of the seedlings survived in the $5 \%$ most resistant families. Average survival of seedlings in Clapper $\mathrm{BC}_{3} \mathrm{~F}_{3}$ families was higher in NCSU trials $(99$ families, mean survival $=$ $24 \%$ ) as compared with Clemson University trials (30 families, mean survival $=7 \%)(F$ test, $P<0.001)$.

High rates of survival were observed for control plants in the NCSU trials that were not inoculated with $P$. cinnamomi. Survival was $91 \%$ for American chestnuts (20 of 22 seedlings), $100 \%$ for Chinese chestnuts ( 20 of 20 seedlings), and $90 \%$ for $\mathrm{BC}_{3} \mathrm{~F}_{3}$ trees ( 258 of 287 seedlings). In Clemson University trials, $P$. cinnamomi was isolated consistently from the roots of diseased plants and container mix samples collected annually from individual tubs. These results confirm that the majority of the mortality of inoculated seedlings could be attributed to Phytophthora root rot and not to other causes.

Heritability of Phytophthora root rot phenotypes among $\mathbf{B C}_{\mathbf{3}} \mathbf{F}_{\mathbf{3}}$ families. Phenotypes associated with resistance to $P$. cinnamomi (i.e., survival, root health, and crown health) were highly heritable $\left(\mathrm{h}^{2}=0.85 \pm 0.09\right.$ to $\left.1.0 \pm 0.11\right)$ among seedlings in Graves $\mathrm{BC}_{3} \mathrm{~F}_{3}$ families over 6 years of evaluation at the three locations (Tables 3 and 4). For Graves $\mathrm{BC}_{3} \mathrm{~F}_{3}$ families included in the 2015 and 2016 NCSU trials, the heritability of survival of seedlings increased rapidly following inoculation and approached a maximum of 1 at 10 to 12 weeks after the first of two inoculations (Fig. 1). In the TACF-USDA Forest Service trial, where seedlings were inoculated once with $P$. cinnamomi, heritability of seedling survival in Graves $\mathrm{BC}_{3} \mathrm{~F}_{3}$ families increased more gradually to $0.8 \pm 0.17$ at 24 weeks (Fig. 1). The Phytophthora root rot phenotypes were less heritable among seedlings in the Clapper $\mathrm{BC}_{3} \mathrm{~F}_{3}$ families $\left(\mathrm{h}^{2}=\right.$ $0.08 \pm 0.07$ to $0.32 \pm 0.08$ ). Survival of seedlings in Clapper $\mathrm{BC}_{3} \mathrm{~F}_{3}$ families was more strongly heritable in trials at NCSU $\left(\mathrm{h}^{2}=0.27 \pm 0.09\right)$ than in Clemson University trials $\left(\mathrm{h}^{2}=0.11 \pm\right.$ 0.08 ) (Tables 3 and 4).

Resistance to $P$. cinnamomi inherited across backcross generations in Graves families. In Clemson University trials, seedlings in families from three backcross generations $\left(\mathrm{BC}_{3}, \mathrm{BC}_{4}\right.$, and $\left.\mathrm{BC}_{3} \mathrm{~F}_{3}\right)$ were evaluated, which enabled an intergenerational comparison of $P$. cinnamomi resistance. Among backcross descendants of the Graves $\mathrm{BC}_{1}$ tree, variation in survival of seedlings in $\mathrm{BC}_{3} \mathrm{~F}_{3}$ and $\mathrm{BC}_{3}$ families was positively skewed and spanned the range of seedling survival in resistant Chinese chestnut and susceptible American chestnut control seedlings (Fig. 2A). By contrast, when root health ratings were used as the phenotype to assess $P$. cinnamomi resistance, the most resistant Graves $\mathrm{BC}_{3} \mathrm{~F}_{3}$ families had resistance intermediate between Chinese chestnut and American chestnut (Fig. 2B). Although resistance of seedlings estimated from root health was less than that of seedlings estimated from survival, root health and seedling survival were strongly genetically correlated among Graves $\mathrm{BC}_{3} \mathrm{~F}_{3}$ families $\left(\mathrm{r}_{\text {genetic }}=0.98 \pm 0.01\right.$, likelihood ratio test $\left.P<0.001\right)$.

Average survival of seedlings in $\mathrm{BC}_{3} \mathrm{~F}_{3}$ families was greater than average survival of seedlings in $\mathrm{BC}_{3}$ families, $\mathrm{BC}_{4}$ families, and American chestnut families (Tukey test, $P<0.05$ ). Survival BLUPs for multiple $\mathrm{BC}_{3} \mathrm{~F}_{3}$ families were regressed on those of single $\mathrm{BC}_{4}$

Table 3. Narrow-sense heritability $\left(\mathrm{h}^{2}\right)$ of survival and root health ratings at 35 to 42 weeks after inoculation with Phytophthora cinnamomi among seedlings

\begin{tabular}{|c|c|c|c|c|c|c|c|c|}
\hline \multirow[b]{2}{*}{ Year } & \multicolumn{2}{|c|}{ Survival $\left(h^{2} \pm S E\right)^{a}$} & \multicolumn{2}{|c|}{ Root health $\left(h^{2} \pm S E\right)^{b}$} & \multicolumn{2}{|c|}{$\begin{array}{c}\text { Number of } \\
\text { families }\end{array}$} & \multicolumn{2}{|c|}{$\begin{array}{l}\text { Median number seedlings } \\
\text { per family (maximum, } \\
\text { minimum) }\end{array}$} \\
\hline & $\mathbf{C}$ & $\mathbf{G}$ & $\mathbf{C}$ & G & $\bar{C}$ & $\bar{G}$ & $\mathbf{C}$ & $\mathbf{G}$ \\
\hline 2012 & $\ldots$ & $0.64 \pm 0.19$ & $\ldots$ & $0.75 \pm 0.20$ & $\ldots$ & 39 & $\ldots$ & $14(5,17)$ \\
\hline 2013 & $0.02 \pm 0.12$ & $1.12 \pm 0.26$ & 0 & $1.18 \pm 0.25$ & 19 & 35 & $13(7,17)$ & $14(5,22)$ \\
\hline 2014 & $\ldots$ & $0.91 \pm 0.28$ & $\ldots$ & $0.72 \pm 0.25$ & $\ldots$ & 19 & $\ldots$ & $26(6,30)$ \\
\hline 2015 & $0.14 \pm 0.10$ & $0.87 \pm 0.38$ & $0.12 \pm 0.09$ & $0.68 \pm 0.32$ & 13 & 9 & $34(23,54)$ & $35(26,37)$ \\
\hline 2016 & $\ldots$ & $0.76 \pm 0.22$ & $\ldots$ & $0.84 \pm 0.23$ & $\ldots$ & 21 & $\ldots$ & $41(34,47)$ \\
\hline 2017 & $\ldots$ & $0.88 \pm 0.26$ & $\ldots$ & $0.62 \pm 0.22$ & $\ldots$ & 17 & $\ldots$ & $27(30,12)$ \\
\hline All years & $0.11 \pm 0.08$ & $0.90 \pm 0.11$ & $0.08 \pm 0.07$ & $0.87 \pm 0.11$ & 32 & 122 & $14(7,54)$ & $16(5,54)$ \\
\hline
\end{tabular}
of American chestnut $\mathrm{BC}_{3} \mathrm{~F}_{3}$ families that descended from the Clapper $(\mathrm{C})$ or Graves $(\mathrm{G}) \mathrm{BC}_{1}$ trees in six Clemson University trials (2012 to 2017)

a Survival of seedlings 20 to 29 weeks after inoculation. SE = standard error.

${ }^{b}$ Root health ratings 20 to 29 weeks after inoculation: $3=$ no lesions on roots, $2=$ lesions on some lateral roots; $1=$ lesions on the tap root or severe root rot on lateral roots; and $0=$ severe root rot, plant dead. 
families that descended from a common $\mathrm{BC}_{3}$ relative, where the $\mathrm{BC}_{3}$ tree was a grandparent of the $\mathrm{BC}_{3} \mathrm{~F}_{3}$ trees and a parent of the $\mathrm{BC}_{4}$ trees (Fig. 3). The slope of the regression line was positive-indicating that inheritance of resistance to $P$. cinnamomi from the $\mathrm{BC}_{3}$ relative was detectable after two generations of intercrossing by open pollination to generate the $\mathrm{BC}_{3} \mathrm{~F}_{3}$ trees. The intercept of the regression line was greater than zero, indicating that $\mathrm{BC}_{3} \mathrm{~F}_{3}$ families were, on average, more resistant than their $\mathrm{BC}_{4}$ relatives. There was a large variation in seedling survival BLUPs among $\mathrm{BC}_{3} \mathrm{~F}_{3}$ families that descended from a common $\mathrm{BC}_{3}$ grandparent.

Minimal $P$. cinnamomi resistance among Clapper families in Clemson University trials. Survival BLUPs for seedlings in Clapper $\mathrm{BC}_{3}, \mathrm{BC}_{4}$, and $\mathrm{BC}_{3} \mathrm{~F}_{3}$ families were, on average, not significantly different from those of susceptible American chestnut families (Fig. 4). Root health BLUPs for Clapper $\mathrm{BC}_{3}$ families were, on average, marginally greater than those for American chestnut (Tukey test, $P=0.027$ )

Resistance to $P$. cinnamomi in NCSU and TACF-USDA Forest Service trials. Similar to results observed in Clemson University trials, genetic variation in survival of seedlings in Graves $\mathrm{BC}_{3} \mathrm{~F}_{3}$ families at 16 weeks spanned the range of variation in survival of seedlings between Chinese chestnut and American chestnut controls in NCSU and TACF-USDA Forest Service trials (Fig. 5A). Genetic variation in crown health was reduced relative to variation in seedling survival (Fig. 5B) but family rankings of seedling survival and crown health were strongly correlated $\left(r_{\text {genetic }}=0.84 \pm 0.03\right)$. Seedlings in Graves $\mathrm{BC}_{3} \mathrm{~F}_{3}$ families had significantly higher average BLUPs for survival and crown health than those in Clapper $\mathrm{BC}_{3} \mathrm{~F}_{3}$ families and American chestnut controls (Tukey test, $P<0.05$ ). Seedlings in Clapper $\mathrm{BC}_{3} \mathrm{~F}_{3}$ families with the greatest resistance in NCSU trials had BLUPs for survival and crown health that were intermediate between the American chestnut and Chinese chestnut controls (Fig. 5). This result contrasts with those from Clemson University trials, where no resistance to $P$. cinnamomi was detected among seedlings in Clapper $\mathrm{BC}_{3} \mathrm{~F}_{3}$ families.

Correlations in survival of seedlings between trials. A strong genetic correlation was observed between survival of seedlings in trials conducted by Clemson University and those in trials conducted by NCSU ( $\mathrm{r}_{\text {genetic }}=0.94 \pm 0.03$, likelihood ratio test $P<0.001$ ) for $53 \mathrm{BC}_{3} \mathrm{~F}_{3}$ families (9 Clapper and 44 Graves) screened by both groups. To test whether mean seedling survival among all families differed between Clemson University and NCSU trials, a regression was performed between the BLUPs for survival of seedling in $\mathrm{BC}_{3} \mathrm{~F}_{3}$ families in the NCSU and Clemson University trials. The slope of the regression line was greater than one ( $t$ test, $P<0.001$ ), indicating that BLUP values for seedling survival in NCSU trials were greater, on average, than those for seedlings in Clemson University trials (Fig. 6A). For seedlings in 17 Graves $\mathrm{BC}_{3} \mathrm{~F}_{3}$ families that were inoculated with $P$. cinnamomi in trials conducted by Clemson University and TACF-USDA Forest Service in 2017, the genetic correlation in seedling survival between the two trial locations was $0.81 \pm 0.13$ (likelihood ratio test $P=0.002$ ), and the slope of the regression line was not significantly different than 1 ( $t$ test, $P>0.05$ ) (Fig. 6B).
Resistance to $C$. parasitica and $P$. cinnamomi was not correlated. The genetic correlation between chestnut blight canker severity and seedling survival after inoculation with $P$. cinna$m o m i$ was not significantly different than zero $\left(\mathrm{r}_{\text {genetic }}=-0.01 \pm\right.$ 0.13 , likelihood ratio test $P=0.1$ ) among 103 Graves $\mathrm{BC}_{3} \mathrm{~F}_{3}$ families (Fig. 7).

\section{Discussion}

Since 1983, TACF has pursued backcross breeding to introduce Chinese chestnut resistance to the chestnut blight fungus (C. parasitica) into hybrids that are expected to have inherited $94 \%$ of their genome from American chestnut parents (Burnham et al. 1986; Diskin et al. 2006; Hebard 2006; Steiner et al. 2017). This program originally did not include evaluating backcross families for resistance to P. cinnamomi, which causes Phytophthora root rot. Fortunately, Chinese chestnut is also resistant to $P$. cinnamomi (Crandall et al. 1945; Jeffers et al. 2009, 2012). Therefore, personnel from Clemson University, Chestnut Return Farms, and TACF began evaluating seedling progeny from a variety of $\mathrm{BC}_{2}$ and $\mathrm{BC}_{3}$ American chestnut backcross trees that had been selected for resistance to $C$. parasitica to determine whether any of these backcross trees had also inherited resistance to $P$. cinnamomi. Significant differences in seedling survival among backcross families inoculated with $P$. cinnamomi were observed each year in trials conducted from 2004 to 2011. Based on these results, it was determined that some $\mathrm{BC}_{2}$ and $\mathrm{BC}_{3}$ American chestnut backcross parents inherited alleles for resistance to $P$. cinnamomi. Consequently, open-pollinated $\mathrm{BC}_{3} \mathrm{~F}_{3}$ progeny of $\mathrm{BC}_{3} \mathrm{~F}_{2}$ trees that descended from the $\mathrm{BC}_{2}$ and $\mathrm{BC}_{3}$ trees evaluated in earlier trials were evaluated for resistance to $P$. cinnamomi from 2012 to 2017 in trials conducted by personnel at Clemson University, NCSU, and TACF (with the USDA Forest Service) to determine which $\mathrm{BC}_{3} \mathrm{~F}_{2}$ parents had inherited resistance to $P$. cinnamomi.

Over the 14-year duration of this project, 18 annual trials were conducted at three locations in two states. Significant differences in seedling survival at 16 to 29 weeks after inoculation with $P$. cinnamomi occurred consistently among American chestnut backcross families in all 18 trials. In these trials, seedling survival was determined at the end of one growing season and was based on a combination of three root rot severity scores that ranged from no symptoms to severe root rot symptoms. We know from years of experience (J. B. James and S. N. Jeffers, unpublished data) that many of the seedlings with severe root rot symptoms do not survive a second growing season after transplanting into pots or in the field; however, survival after one growing season has proven to be the best parameter for identifying differences in resistance to $P$. cinnamomi among seedlings in backcross families under the experimental conditions used in these trials.

Differences in survival and average root heath ratings among backcross families were highly heritable, suggesting that the root health and survival phenotypes of individual trees accurately reflects their underlying genetic resistance to $P$. cinnamomi. Correlated survival within backcross families that were inoculated with different isolates of $P$. cinnamomi at multiple screening locations in different

Table 4. Narrow-sense heritability $\left(\mathrm{h}^{2}\right)$ of survival and crown health ratings at 16 weeks after inoculation with Phytophthora cinnamomi among seedlings of American chestnut $\mathrm{BC}_{3} \mathrm{~F}_{3}$ families that descended from the Clapper $(\mathrm{C})$ or Graves $(\mathrm{G}) \mathrm{BC}_{1}$ trees in three North Carolina State University trials (2014 to 2016) and one trial conducted by The American Chestnut Foundation and the United States Department of Agriculture Forest Service (2017)

\begin{tabular}{|c|c|c|c|c|c|c|c|c|}
\hline \multirow[b]{2}{*}{ Year } & \multicolumn{2}{|c|}{ Survival $\left(h^{2} \pm S E\right)^{a}$} & \multicolumn{2}{|c|}{ Crown health $\left(h^{2} \pm S E\right)^{b}$} & \multicolumn{2}{|c|}{$\begin{array}{l}\text { Number } \\
\text { families }\end{array}$} & \multicolumn{2}{|c|}{$\begin{array}{l}\text { Median number seedlings } \\
\text { per family (maximum, } \\
\text { minimum) }\end{array}$} \\
\hline & C & $\mathbf{G}$ & $\mathbf{C}$ & G & $\mathrm{C}$ & $\mathbf{G}$ & C & G \\
\hline 2014 & $0.33 \pm 0.08$ & $0.66 \pm 0.24$ & $0.38 \pm 0.08$ & $0.72 \pm 0.25$ & 78 & 17 & $25(10,31)$ & $23(18,28)$ \\
\hline 2015 & $0.20 \pm 0.11$ & $0.92 \pm 0.15$ & $0.28 \pm 0.13$ & $1.0 \pm 0.16$ & 28 & 69 & $20(14,21)$ & $20(10,22)$ \\
\hline 2016 & $\ldots$ & $1.13 \pm 0.16$ & $\ldots$ & $1.13 \pm 0.16$ & $\ldots$ & 75 & $\ldots$ & $20(18,22)$ \\
\hline 2017 & $\ldots$ & $0.74 \pm 0.17$ & $\ldots$ & $\ldots$ & $\ldots$ & 37 & $\ldots$ & $30(7,40)$ \\
\hline All years & $0.27 \pm 0.09$ & $0.85 \pm 0.09$ & $0.32 \pm 0.08$ & $1.0 \pm 0.11$ & 99 & 189 & $24(10,49)$ & $20(7,57)$ \\
\hline
\end{tabular}

${ }^{\text {a }}$ Survival of stems 16 weeks after inoculation. SE $=$ standard error.

${ }^{\mathrm{b}}$ Crown health is percentage of crown that had wilted 16 weeks after inoculation. 
years further confirmed that our trials accurately measured the genetic component of $P$. cinnamomi resistance despite differences in experimental conditions.

A number of observations supported the hypothesis that backcross descendants of the Graves $\mathrm{BC}_{1}$ tree inherited major-effect alleles for $P$. cinnamomi resistance from Mahogany, the C. mollissima grandparent of Graves. Chinese chestnut control seedlings survived at a high level (97\%) whereas American chestnut controls survived at a low level (11\%), which confirmed that $P$. cinnamomi resistance in backcross trees was conferred by alleles inherited from $C$. mollissima. The Graves $\mathrm{BC}_{3}$ and $\mathrm{BC}_{3} \mathrm{~F}_{3}$ families that were most resistant to $P$. cinnamomi had seedling survival percentages that approached those of resistant Chinese chestnut seedlings. Third-backcross trees are expected to only have inherited 1/16th of their genome from C. mollissima (Steiner et al. 2017); therefore, major-effect alleles for $P$. cinnamomi resistance were expected to be located on small segments of backcross genomes inherited from $C$. mollissima. It is remarkable that alleles for resistance to $P$. cinnamomi that were inherited from $C$. mollissima had not been bred out through backcrossing to $C$. dentata because TACF did not select for resistance to $P$. cinnamomi.

We showed in this study that chestnut blight canker severity and Phytophthora root rot survival were not genetically correlated among Graves $\mathrm{BC}_{3} \mathrm{~F}_{3}$ families; therefore, major-effect alleles for $P$. cinnamomi resistance are expected to be unlinked with alleles for blight resistance. Quantitative trait locus (QTL) mapping supports the hypothesis that alleles that confer resistance to $C$. parasitica and $P$. cinnamomi are not linked. Among C. mollissima $\times C$. dentata $\mathrm{F}_{2}$ progeny of the Mahogany C. mollissima tree, QTLs for blight resistance were detected on linkage groups $\mathrm{B}, \mathrm{F}$, and $\mathrm{G}$ (Kubisiak et al. 1997, 2013). Among $\mathrm{BC}_{1}$ descendants of another $C$. mollissima tree, a QTL for resistance to $P$. cinnamomi was first detected on linkage group E by Kubisiak (2010). By reanalyzing Kubisiak's data, Olukolu et al. (2012) found an additional locus on linkage group E plus a locus on linkage group $\mathrm{A}$. Using much larger $\mathrm{BC}_{1}$ families from two C. mollissima trees (Mahogany and the one used by Kubisiak), T. Zhebentyayeva (personal communication) confirmed

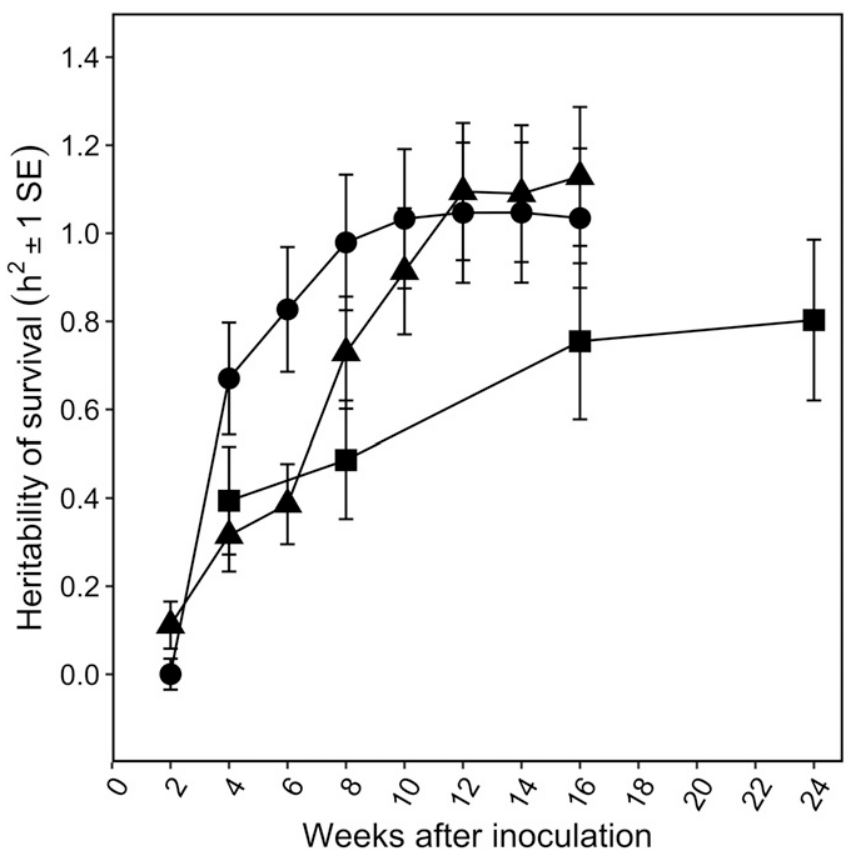

Fig. 1. Heritability ( $h^{2} \pm 1$ standard error) of survival of chestnut seedlings in Graves $\mathrm{BC}_{3} \mathrm{~F}_{3}$ families over time after inoculation with Phytophthora cinnamomi. Seedlings were inoculated twice in the North Carolina State University trials in 2015 (circles) and 2016 (triangles) at 0 and 8 weeks, whereas seedlings were inoculated once in The American Chestnut Foundation-United States Department of Agriculture Forest Service trial in 2017 (squares). the two resistance loci on linkage group $\mathrm{E}$ and found an additional locus for resistance on linkage group K. QTLs for resistance to $P$. cinnamomi also were discovered on linkage groups $\mathrm{E}$ and $\mathrm{K}$ among $C$. sativa $\times$ C. crenata $\mathrm{F}_{1}$ hybrids (Santos et al. 2017). These results suggest that Japanese chestnut $(C$. crenata $)$ and Chinese chestnut share common loci that confer resistance to $P$. cinnamomi.

Our results suggest that alleles for $P$. cinnamomi resistance have dominant effects. Average and maximum survival and root heath scores among seedlings in $\mathrm{BC}_{3}$ families, which are at best heterozygous for alleles that confer resistance to $P$. cinnamomi, had marginally lower survival and root health scores as compared with seedlings in $\mathrm{BC}_{3} \mathrm{~F}_{3}$ families. The $\mathrm{BC}_{3} \mathrm{~F}_{3}$ progenies were generated from two generations of intercrossing among $\mathrm{BC}_{3}$ and $\mathrm{BC}_{3} \mathrm{~F}_{2}$ trees. Thus, $\mathrm{BC}_{3} \mathrm{~F}_{3}$ trees potentially inherited $P$. cinnamomi resistance alleles from both parents in a homozygous state. The observation that survival of the most resistant heterozygous $\mathrm{BC}_{3}$ families was similar to that of the most resistant and potentially homozygous $\mathrm{BC}_{3} \mathrm{~F}_{3}$ families suggests that random intercrossing among $\mathrm{BC}_{3}$ and $\mathrm{BC}_{3} \mathrm{~F}_{2}$ trees selected for resistance to $C$. parasitica rarely generates progeny that are homozygous for $P$. cinnamomi resistance alleles at one or more loci. Regardless, the greater average resistance and wide segregation for $P$. cinnamomi resistance among seedlings in $\mathrm{BC}_{3} \mathrm{~F}_{3}$ families as compared with $\mathrm{BC}_{4}$ progeny that descended from common $\mathrm{BC}_{3}$ trees suggests that intercrossing backcross trees selected for resistance to $P$. cinnamomi has the potential to enhance $P$. cinnamomi resistance in the subsequent generation.

The observation that seedlings in the most resistant Graves $\mathrm{BC}_{3} \mathrm{~F}_{3}$ families had root health that was intermediate between Chinese and American chestnut suggests that Graves $\mathrm{BC}_{3} \mathrm{~F}_{2}$ and $\mathrm{BC}_{3} \mathrm{~F}_{3}$ progeny did not inherit the full complement of $P$. cinnamomi resistance alleles from the $C$. mollissima Mahogany tree in a homozygous state. Resistance to $P$. cinnamomi may be enhanced to levels similar to $C$. mollissima trees through controlled pollinations between the most resistant backcross trees and additional selection for $P$. cinnamomi resistance among their progenies.

Our results were inconclusive as to whether descendants of Clapper inherited little to no resistance to $P$. cinnamomi, as suggested by Clemson University trials, or intermediate levels of resistance, as suggested by NCSU trials. Backcross descendants of Clapper may have inherited fewer or smaller-effect resistance alleles as compared with descendants of Graves. Alternatively, $\mathrm{BC}_{3} \mathrm{~F}_{2}$ progeny of Clapper $\mathrm{BC}_{3}$ mothers may have inherited resistance to $P$. cinnamomi from neighboring Graves $\mathrm{BC}_{3}$ trees, more distant $C$. dentata backcross

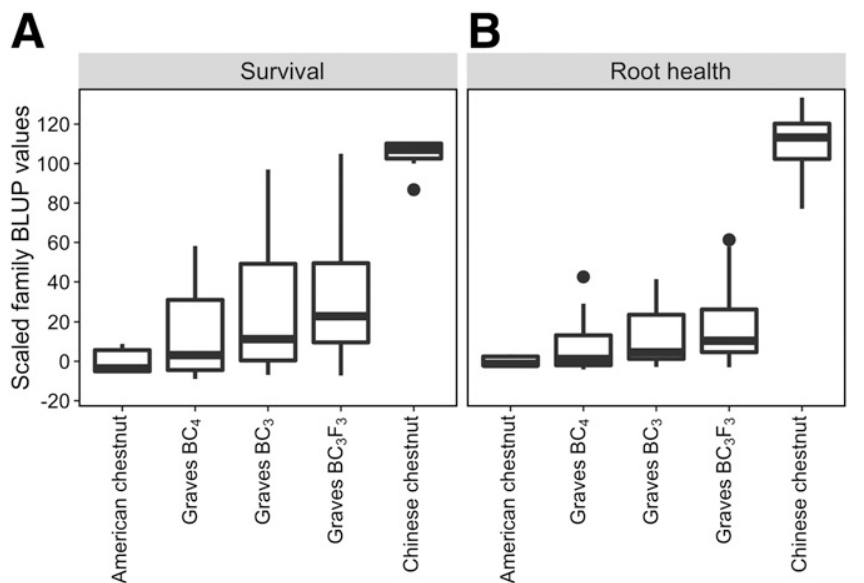

Fig. 2. Genetic variation in $\mathbf{A}$, survival and $\mathbf{B}$, root health among backcross descendants of the Graves chestnut tree 35 to 42 weeks after inoculation with Phytophthora cinnamomi in Clemson University trials. Box-plots were created from variation in best linear unbiased predictions (BLUPs) of survival and root health among $18 \mathrm{BC}_{3}$ families, $46 \mathrm{BC}_{4}$ families, $122 \mathrm{BC}_{3} \mathrm{~F}_{3}$ families, 13 Chinese chestnut families, and 13 American chestnut families. The BLUPs were scaled from 0 (American chestnut mean) to 100 (Chinese chestnut mean). 
descendants of additional C. mollissima trees, or pure C. mollissima trees that were planted on the same farm as the Clapper $\mathrm{BC}_{3}$ trees.

Large numbers of $\mathrm{BC}_{3} \mathrm{~F}_{2}$ progeny were needed to generate a subset of progeny that were homozygous for multiple blight resistance alleles; therefore, open pollination among $\mathrm{BC}_{3}$ trees was used to generate $\mathrm{BC}_{3} \mathrm{~F}_{2}$ trees (Steiner et al. 2017). Individual Clapper $\mathrm{BC}_{3}$ selections were planted within 2.1 to $475 \mathrm{~m}$ (average distance $=154 \mathrm{~m}$ ) of other Clapper $\mathrm{BC}_{3}$ selections. Maximum pollination occurs among trees that are less than $30 \mathrm{~m}$ apart and the likelihood of pollination

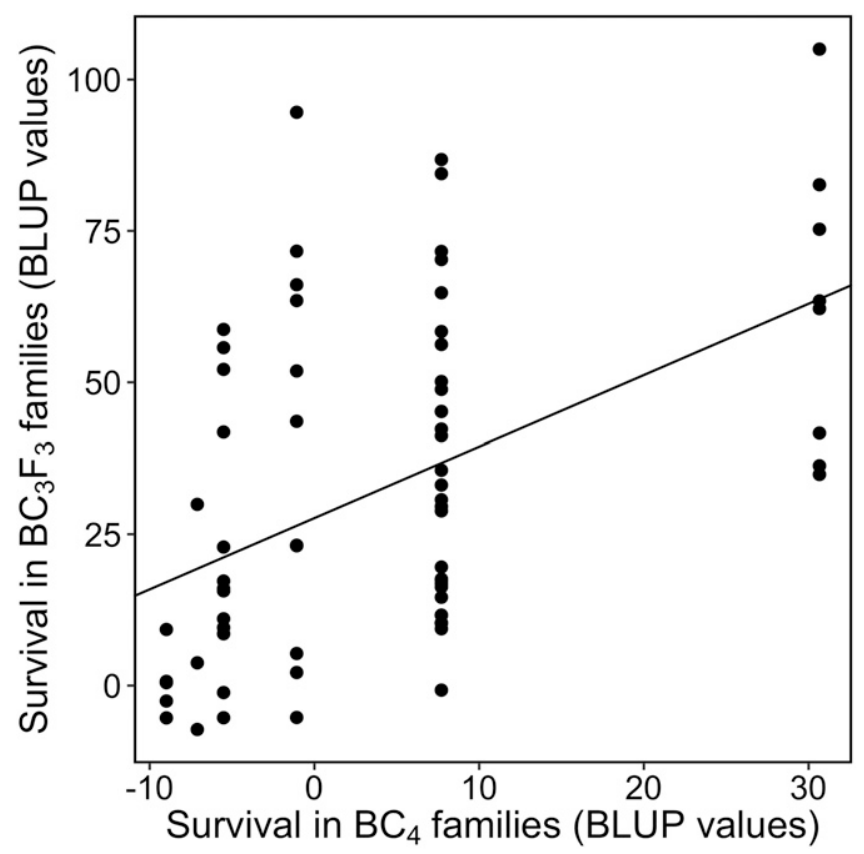

Fig. 3. In trials conducted by Clemson University, survival of chestnut seedlings after inoculation with Phytophthora cinnamomi in multiple Graves $\mathrm{BC}_{3} \mathrm{~F}_{3}$ families versus single Graves $\mathrm{BC}_{4}$ families that shared a common $\mathrm{BC}_{3}$ ancestor. The $\mathrm{BC}_{3}$ ancestor is a grandparent of the $\mathrm{BC}_{3} \mathrm{~F}_{3}$ trees and a parent of the $\mathrm{BC}_{4}$ trees. Best linear unbiased predictions (BLUPs) of survival were scaled from 0 (American chestnut mean) to 100 (Chinese chestnut mean). The regression line is the least squares regression of $\mathrm{BC}_{3} \mathrm{~F}_{3}$ versus $\mathrm{BC}_{4}$ survival in BLUPs.

A

B

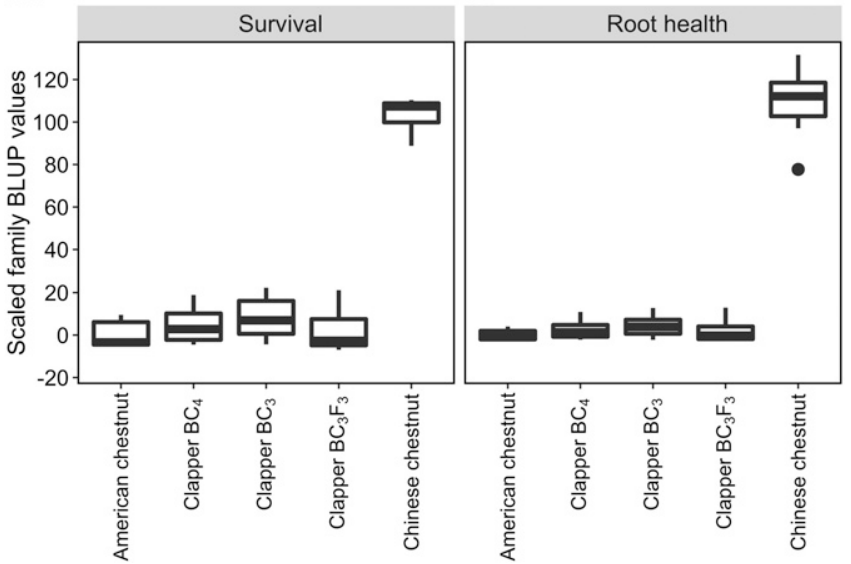

Fig. 4. Genetic variation in A, survival and $\mathbf{B}$, root health among backcross descendants from the Clapper chestnut tree at 35 to 42 weeks after inoculation with Phytophthora cinnamomi in Clemson University trials. Box-plots were created from variation in best linear unbiased predictions (BLUPs) of survival and root health among $10 \mathrm{BC}_{3}$ families, $20 \mathrm{BC}_{4}$ families, $32 \mathrm{BC}_{3} \mathrm{~F}_{3}$ families, 13 Chinese chestnut families, and 13 American chestnut families. The BLUPs were scaled from 0 (American chestnut mean) to 100 (Chinese chestnut mean). decreases exponentially as distance between trees increases (Rutter 1990). Consequently, it is likely that most of the Clapper $\mathrm{BC}_{3} \mathrm{~F}_{2}$ trees were the progeny of Clapper $\mathrm{BC}_{3} \times \mathrm{BC}_{3}$ crosses. However, with open pollination, it is possible that a subset of the trees referred to as Clapper $\mathrm{BC}_{3} \mathrm{~F}_{2} \mathrm{~S}$ were the progeny of Clapper $\mathrm{BC}_{3}$ mothers pollinated by trees other than Clapper $\mathrm{BC}_{3}$ fathers. The Clapper $\mathrm{BC}_{3}$ selections were planted 15 to $548 \mathrm{~m}$ (average distance $=$ $234 \mathrm{~m}$ ) from Graves $\mathrm{BC}_{3}$ selections and a minimum of $140 \mathrm{~m}$ from Chinese chestnuts on TACF Glenn C. Price Farm in Meadowview, VA. These pollen sources may have contributed alleles for resistance to $P$. cinnamomi to Clapper $\mathrm{BC}_{3} \mathrm{~F}_{2}$ and $\mathrm{BC}_{3} \mathrm{~F}_{3}$ seedlings. A larger number of Clapper $\mathrm{BC}_{3} \mathrm{~F}_{3}$ families were screened in NCSU trials ( 99 families) as compared with Clemson trials ( 32 families). Therefore, it is more likely that NCSU trials detected partial resistance in Clapper or pollen contamination. Genotyping of Clapper and Graves $\mathrm{BC}_{3}$ and $\mathrm{BC}_{3} \mathrm{~F}_{2}$ trees as well as pure Chinese and American chestnut trees is ongoing ( $\mathrm{J}$. Westbrook and J. Holliday, unpublished). With these data, we will be able to determine whether Clapper and Graves $\mathrm{BC}_{3}$ trees intercrossed to generate Clapper $\times$ Graves $\mathrm{BC}_{3} \mathrm{~F}_{2}$ trees and whether any of the $\mathrm{BC}_{3} \mathrm{~F}_{2}$ trees were the progeny of outcrosses to Chinese chestnuts.

Selection for resistance to $P$. cinnamomi from within a diverse backcross breeding population is the first step toward breeding to combine resistance to $C$. parasitica and $P$. cinnamomi. Additional evaluation for resistance to $P$. cinnamomi will focus primarily on descendants of the Graves tree due to the greater potential for gains in resistance as compared with descendants of the Clapper tree. Within TACF's national breeding program, in total, 181 backcross lines that descended from the Graves tree have been generated by breeding $\mathrm{BC}_{2}$ and $\mathrm{BC}_{3}$ selections from the Meadowview farm with wild-type American chestnut trees with locations ranging from Maine to Georgia (Westbrook 2018a). To date, only $\mathrm{BC}_{3} \mathrm{~F}_{3}$ trees from the Meadowview farm breeding program, which are descendants of American chestnuts from southwest Virginia, have been screened for resistance to $P$. cinnamomi. Starting in 2018 , TACF began to increase the genetic diversity of backcross trees selected for resistance to $P$. cinnamomi by screening Graves $\mathrm{BC}_{3} \mathrm{~F}_{2}$ and $\mathrm{BC}_{4} \mathrm{~F}_{2}$ descendants of American chestnuts from Maine, Vermont, New Hampshire, Massachusetts, Pennsylvania, northern Virginia, Kentucky, North Carolina, South Carolina, and Georgia. Forty progeny per $\mathrm{BC}_{3}$ or $\mathrm{BC}_{4}$ parent were inoculated with $P$. cinnamomi. Progeny that survive inoculation with $P$. cinnamomi will be planted at orchard sites where $P$. cinnamomi is already present so that seedlings will

A

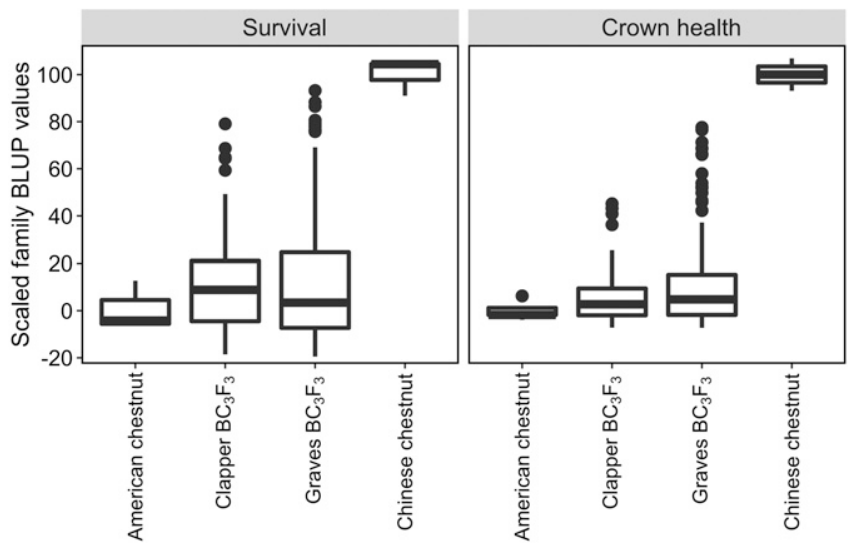

Fig. 5. Genetic variation in A, survival and $\mathbf{B}$, crown health among chestnut seedlings in $\mathrm{BC}_{3} \mathrm{~F}_{3}$ families that descended from the Clapper and Graves trees. Box-plots were created from variation in best linear unbiased predictions (BLUPs) of survival and crown health 16 weeks after inoculation with $P$. cinnamomi; 99 Clapper $\mathrm{BC}_{3} \mathrm{~F}_{3}$ families, 189 Graves $\mathrm{BC}_{3} \mathrm{~F}_{3}$ families, 4 American chestnut families, and 4 Chinese chestnut families included in three North Carolina State University trials and one The American Chestnut Foundation-United States Department of Agriculture Forest Service trial. The BLUPs were scaled from 0 (American chestnut mean) to 100 (Chinese chestnut mean). 
also be exposed to the pathogen in natural settings. The final objective is to obtain at least one flowering $\mathrm{BC}_{3} \mathrm{~F}_{2}$ or $\mathrm{BC}_{4} \mathrm{~F}_{2}$ seedling from each $\mathrm{BC}_{3}$ or $\mathrm{BC}_{4}$ mother tree with improved resistance to P. cinnamomi.

Considering that resistance to $C$. parasitica and resistance to $P$. cinnamomi are not correlated, additional breeding and selection will be required to combine the resistances to these two pathogens. It is not feasible to select trees in the current $\mathrm{BC}_{3} \mathrm{~F}_{2}$ generation that inherited high levels of resistance to both $C$. parasitica and $P$. cinnamomi. In screening for resistance to $C$. parasitica in the $\mathrm{BC}_{3} \mathrm{~F}_{2}$ generation, TACF selects 1 of 150 trees (Steiner et al. 2017). Even with this high selection intensity, the selected trees are predicted to have $C$. parasitica resistance that is intermediate between Chinese chestnut and American chestnut. Additional selection for P. cinnamomi resistance would be required, leaving too few selections for further intercrossing.

One potential breeding strategy to combine resistance to both pathogens is to cross $\mathrm{BC}_{3} \mathrm{~F}_{2}$ (or $\mathrm{BC}_{4} \mathrm{~F}_{2}$ ) trees selected for resistance to $P$. cinnamomi with $\mathrm{BC}_{3} \mathrm{~F}_{2}$ trees that have been selected for resistance to $C$. parasitica. The $\mathrm{BC}_{3} \mathrm{~F}_{3}$ progeny would be evaluated for resistance to $P$. cinnamomi first; then, survivors would be evaluated for resistance to $C$. parasitica. Another generation of intercrossing and selection for resistance to both pathogens would be required to obtain selections that are homozygous for alleles that confer resistance to both pathogens. A challenge to this strategy is that it requires large numbers of progeny from each cross due to multigenic control of the resistances to both pathogens, and it is difficult to obtain large numbers of seed through controlled pollinations. We estimate that at least $200 \mathrm{BC}_{3} \mathrm{~F}_{3}$ progeny per cross would need to be evaluated to obtain one progeny with high levels of resistance to both pathogens.

A second breeding strategy is to outcross descendants of transgenic C. parasitica-resistant American chestnut trees with P. cinnamomiresistant backcross trees. Collaborators at the State University of New York in Syracuse have developed a transgenic American chestnut tree that is resistant to $C$. parasitica by overexpressing the oxalate oxidase $(\mathrm{OxO})$ gene from wheat (Zhang et al. 2013). When the transgenic trees are outcrossed with wild-type American chestnut trees, approximately $50 \%$ of the progeny that inherited the OxO gene have been demonstrated to have high levels of resistance after artificial inoculation with $C$. parasitica (Newhouse et al. 2014). By simplifying the genetics of $C$. parasitica resistance to a single transgene with a dominant effect, as few as 40 to 80 progeny per cross between a transgenic tree and a $P$. cinnamomi-resistant backcross tree may be sufficient to generate selections that inherited the $\mathrm{OxO}$ gene and major-effect $P$. cinnamomi resistance alleles. The inheritance of the

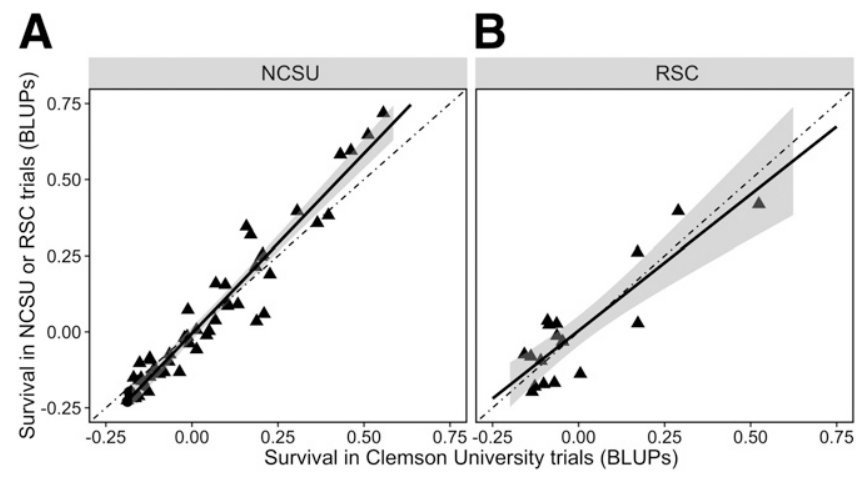

Fig. 6. Genetic correlation of chestnut seedling survival within $\mathrm{BC}_{3} \mathrm{~F}_{3}$ families inoculated with Phytophthora cinnamomi at different geographic locations: A, 44 Graves families (triangles) and 9 Clapper families (circles) were evaluated in trials conducted simultaneously by Clemson University and North Carolina State University (NCSU); B, 17 Graves families were evaluated in trials conducted simultaneously by Clemson University and The American Chestnut Foundation-United States Department of Agriculture Forest Service Resistance Screening Center (RSC). The least squares regression line $\pm 95 \%$ confidence interval (solid line) is compared with the 1:1 line (dashed line).
OxO gene can be detected without inoculation with $C$. parasitica by using an enzymatic assay to detect $\mathrm{OxO}$ activity in plant tissue (Zhang et al. 2013). Progeny that inherit the OxO gene will then be screened for resistance to $P$. cinnamomi. Surviving plants will be planted at orchard locations where $P$. cinnamomi already is present in the soil. Selections will be intercrossed to generate progeny that inherited both the $\mathrm{OxO}$ gene and $P$. cinnamomi resistance alleles in a homozygous state.

Currently, one transgenic insertion of the $\mathrm{OxO}$ gene into one American chestnut tree from New York is being considered for deregulated status by the U.S. federal government (W. Powell, personal communication). If regulatory approval is obtained, three generations of outcrossing the transgenic founder clone to wild-type American chestnuts and backcross trees will be required to expand the effective population size to $>500$ (Westbrook 2018b). Resistance to $C$. parasitica and P. cinnamomi will be combined in the final generation of outcrossing so that selection for $\mathrm{OxO}$ activity and $P$. cinnamomi resistance will be required only after the final outcross and first intercross generations (Westbrook 2018a). It is estimated that it will take 15 to 35 years from the time of federal regulatory approval to release transgenic trees to complete five additional generations of breeding (i.e., three outcross generations and two intercross generations) to combine resistance to these two pathogens within a genetically diverse population that is homozygous for resistance to both pathogens (Westbrook 2018b). The intermediate objective of combining resistance to these pathogens in a less genetically diverse population may be accomplished within 10 years of the release of transgenic trees. This objective will require one generation of breeding between transgenic trees resistant to $C$. parasitica and backcross trees resistant to $P$. cinnamomi, selection among the progeny, and intercrossing among the selections to generate large quantities of seed.

In conclusion, restoration of American chestnut trees depends on combining resistance to $C$. parasitica and $P$. cinnamomi, two pathogens that have effectively eliminated this tree species from forests in the eastern United States. Resistance must be combined within breeding populations that are sufficiently diverse so that the species may continue to evolve within its native range. Our results demonstrate that American chestnut backcross descendants of one of TACF's sources of resistance to $C$. parasitica also have inherited major-effect

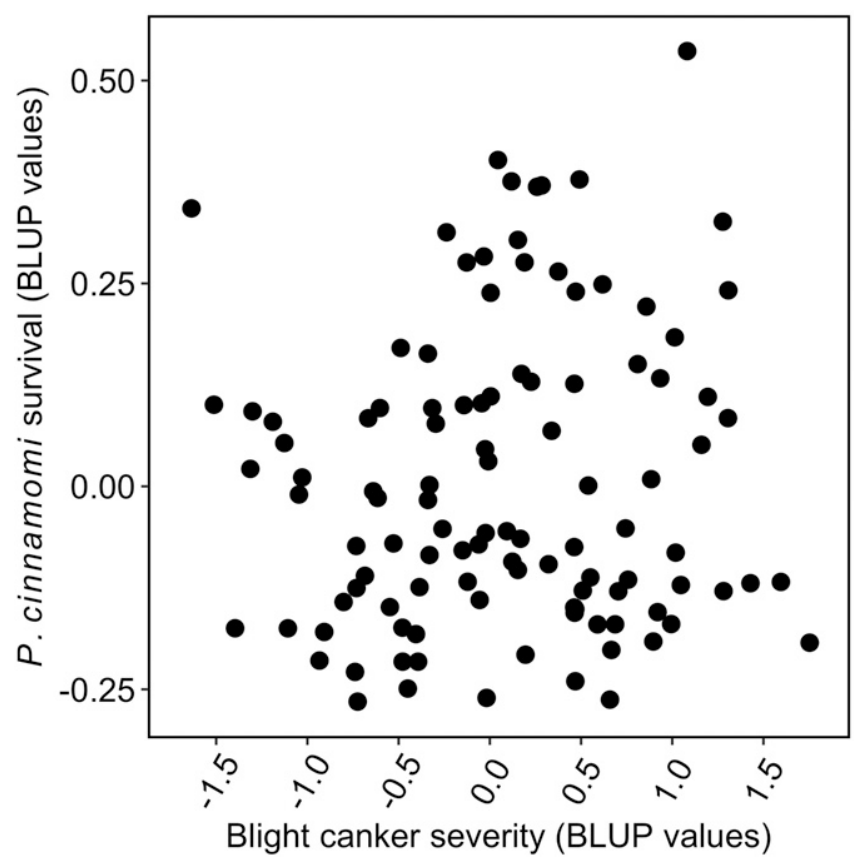

Fig. 7. Genetic correlation between survival after inoculation with Phytophthora cinnamomi and chestnut blight canker severity (best linear unbiased predictions [BLUP] values) among chestnut seedlings from 103 Graves $\mathrm{BC}_{3} \mathrm{~F}_{3}$ families. 
alleles for resistance to $P$. cinnamomi. Future selection for $P$. cinnamomi resistance in backcross populations and breeding these trees with $C$. parasitica-resistant backcross and transgenic trees will be used to produce trees with resistance to both pathogens.

\section{Acknowledgments}

We thank the members and volunteers of and the donors to The American Chestnut Foundation who have provided long-term financial support, moral support, and labor for the mission to restore the American chestnut to its native range; the many people who assisted with the Clemson University trials that were conducted in collaboration with Chestnut Return Farms over 14 years, including R. Baker, S. Barilovitz, S. Barilovitz, Jr., P. Bowers, R. Cain, E. R. Camacho, C. Colburn, C. Collier, D. Dlugos, D. Drechsler, L. Georgi, A. Gitto, B. Glenn, M. Greene, B. Harrelson, F. Hebard, T. Hodge, J. Hodges, J. Hwang, J. Jeffers, M. Jeffers, C. Kennedy, P. Laurie, L. Luszcz, F. McLaughlin, I. Meadows, S. Oak, B. Paris, J. Payne, T. Perkins, E. Perry, C. Santos, S. Schreier, E. Schwartzman, C. Scott, J. Sevic, S. Sharpe, J. Vissage, Y. Wamishe, T. Watson, W. White, T. Zhebentyayeva, and D. Zwart; R. Blaedow, K. Frick, B. Jarrett, B. Minton, E. Schwartzman, and B. Williams at the USDA Forest Service Resistance Screening Center, who assisted with Phytophthora root rot evaluation; A. M. Braham at NCSU for supervising and conducting the inoculation procedure; and T. Allison, M. Escanfarla, W. Kohlway, Y. Kurt, J. Pearson, R. Porter, and C. Williams for assisting with inoculum preparation, inoculation, and phenotypic assessments

\section{Literature Cited}

Anagnostakis, S. L. 2001. The effect of multiple importations of pests and pathogens on a native tree. Biol. Invas. 3:245-254

Anagnostakis, S. L. 2007. The chestnut plantation at Sleeping Giant: The legacy of Arthur Harmount Graves. J. Am. Chestnut Found. 21:34-39.

Anagnostakis, S. L. 2012. Chestnut breeding in the United States for disease and insect resistance. Plant Dis. 96:1392-1403.

Arnhold, E. 2013. Pacote em ambiente R para análise de variância e análises complementares [Package in the $\mathrm{R}$ environment for analysis of variance and complementary analyses]. Braz. J. Vet. Res. Anim. Sci. 50:488-492.

Balci, Y., Balci, S., Eggers, J., MacDonald, W. L., Juzwik, J., Long, R. P., and Gottschalk, K. W. 2007. Phytophthora spp. associated with forest soils in eastern and north-central US oak ecosystems. Plant Dis. 91:705-710.

Benson, D. M. 1982. Cold inactivation of Phytophthora cinnamomi. Phytopathology 72:560-563.

Burgess, T. I., Scott, J. K., Mcdougall, K. L., Stukely, M. J. C., Crane, C., Dunstan, W. A., Brigg, F., Andjic, V., White, D., Rudman, T., Arentz, F., Ota, N., and Hardy, G. E. 2017. Current and projected global distribution of Phytophthora cinnamomi, one of the world's worst plant pathogens. Glob. Change Biol. 23:1661-1674.

Burnham, C. R., Rutter, P. A., and French, D. W. 1986. Breeding blight-resistant chestnuts. Plant Breed. Rev. 4:346-397.

Butler, D. G., Cullis, B. R., Gilmour, A. R., and Gogel, B. J. 2009. ASReml-R Reference Manual: Mixed Models for S Language Environments. The State of Queensland Department of Primary Industries and Fisheries, Brisbane, QLD, Australia.

Clapper, R. B. 1952. Relative blight resistance of some chestnut species and hybrids. J. For. 50:453-455.

Crandall, B. S., and Gravatt, G. F. 1967. The distribution of Phytophthora cinnamomi. Part II-Geographic distribution. Ceiba 13:57-78.

Crandall, B. S., Gravatt, G. F., and Ryan, M. M. 1945. Root disease of Castanea species and some coniferous broadleaf nursery stocks, caused by Phytophthora cinnamomi. Phytopathology 35:162-180.

Diskin, M., Steiner, K. C., and Hebard, F. V. 2006. Recovery of American chestnut characteristics following hybridization and backcross breeding to restore blightravaged Castanea dentata. For. Ecol. Manage. 223:439-447.

Ferguson, A. J., and Jeffers, S. N. 1999. Detecting multiple species of Phytophthora in container mixes from ornamental crop nurseries. Plant Dis. 83:1129-1136.

Frampton, J., Isik, F., and Benson, D. M. 2013. Genetic variation in resistance to Phytophthora cinnamomi in seedlings of two Turkish Abies species. Tree Genet. Genomes 9:53-63.

Freinkel, S. 2007. American Chestnut. The Life, Death, and Rebirth of a Perfect Tree. University of California Press, Berkeley, CA, U.S.A

Hebard, F. 2006. The backcross breeding program of The American Chestnut Foundation. Pages 61-77 in: Restoration of American Chestnut to Forest Lands-Proc. Conf. Workshop, The North Carolina Arboretum. K. C. Steiner and J. E. Carlson, eds. Natural Resources Report NPS/NCR/CUE/NRR-2006/ 001. National Park Service, Washington, DC

Holmes, K. A., and Benson, D. M. 1994. Evaluation of Phytophthora parasitica var. nicotianae for biocontrol of Phytophthora parasitica on Catharanthus roseus. Plant Dis. 78:193-199.

Jacobs, D. F. 2007. Toward development of silvical strategies for forest restoration of American chestnut (Castanea dentata) using blight-resistant hybrids. Biol. Conserv. 137:497-506.

James, J. B. 2011a. Phytophthora: The stealthy killer. J. Am. Chestnut Found. 25: $9-11$.
James, J. B. 2011b. Phytophthora: The stealthy killer Part 2. J. Am. Chestnut Found. 25:14-17.

Jeffers, S. N. 2015. Protocol 07-04.1: PARP(H)-V8A. In: Laboratory Protocols for Phytophthora species. K. Ivors, ed. American Phytopathological Society, St. Paul, MN, U.S.A.

Jeffers, S. N., James, J. B., and Sisco, P. H. 2009. Screening for resistance to Phytophthora cinnamomi in hybrid seedlings of American chestnut. Pages 188-194 in: Proc. Fourth Meet. Int. Union For. Res. Organ. (IUFRO) Working Party S07.02.09: Phytophthoras in Forests \& Natural Ecosystems. E. M. Goheen and S. J., Frankel, tech. coords. Gen. Tech. Rep. PSW-GTR-221. U.S. Dep. Agric. For. Serv., Pacific Southwest Research Station, Albany, CA, U.S.A.

Jeffers, S. N., Meadows, I. M., James, J. B., and Sisco, P. H. 2012. Resistance to Phytophthora cinnamomi among seedlings from backcross families of hybrid American chestnut. Pages 194-195 in: Proc. Fourth Int. Workshop Genet. Host-Parasite Interactions in Forestry: Disease and Insect Resistance in Forest Trees. R. A. Sniezko A. D. Yanchuk, J. T. Kliejunas, K. M. Palmieri, J. M. Alexander, and S. J. Frankel, tech. coords. Gen. Tech. Rep. PSW-GTR 240. U.S. Dep. Agric. For. Serv., Pacific Southwest Research Station, Albany, CA, U.S.A.

Jung, T., Jung, M. H., Scanu, B., Seress, D., Kovács, G. M., Maia, C., Pérez-Sierra, A., Chang, T. T., Chandelier, A., Heungens, K., van Poucke, K., Abad-Campos, P., Léon, M., Cacciola, S. O., and Bakonyi, J. 2017. Six new Phytophthora species from ITS Clade 7a including two sexually functional heterothallic hybrid species detected in natural ecosystems in Taiwan. Persoonia 38:100-135

Kubisiak, T. 2010. NE-1333 Technical Committee Meeting Minutes. https:// ecosystems.psu.edu/research/chestnut/meetings/crees-ne-projects/minutes-pdfs/ 2010-research-meeting-minutes

Kubisiak, T., Hebard, F., Nelson, C., Jhang, J., Bernatzky, R., Huang, H., Anagnostakis, S., and Doudrick, R. 1997. Molecular mapping of resistance to blight in an interspecific cross in the genus Castanea. Phytopathology 87: 751-759.

Kubisiak, T. L., Nelson, C. D., Staton, M. E., Zhebentyayeva, T., Smith, C. Olukolu, B. A., Fang, G.-C., Hebard, F. V., Anagnostakis, S., Wheeler, N., Sisco, P. H., Abbott, A. G., and Sederoff, R. R. 2013. A transcriptome-based genetic map of Chinese chestnut (Castanea mollissima) and identification of regions of segmental homology with peach (Prunus persica). Tree Genet. Genomes 9:557-571

Laurie, P. 2014. The once and future perfect tree. S. C. Wildl. 10:4-9.

Lynch, M., and Walsh, B. 1998. Genetics and Analysis of Quantitative Traits Sinauer Associates, Sunderland, MA, U.S.A.

Meadows, I. M., and Jeffers, S. N. 2011. Distribution and recovery of Phytophthora cinnamomi in soils of mixed hardwood-pine forests of the south-eastern USA. N. Z. J. For. Sci. 41S:S39-S47.

Meadows, I. M., Zwart, D. C., Jeffers, S. N., Waldrop, T. A., and Bridges, W. C. 2011. Effects of fuel reduction treatments on incidence of Phytophthora species in soil of a southern Appalachian Mountain forest. Plant Dis. 95:811-820.

Newhouse, A. E., McGuigan, L. D., Baier, K. A., Valletta, K. E., Rottmann, W. H., Tschaplinski, T. J., Maynard, C. A., and Powell, W. A. 2014. Transgenic American chestnuts show enhanced blight resistance and transmit the trait to $\mathrm{T}_{1}$ progeny. Plant Sci. 228:88-97.

Olukolu, B. A., Nelson, C. D., and Abbott, A. G. 2012. Mapping resistance to Phytophthora cinnamomi in chestnut (Castanea sp.). Page 177 in: Proc. Fourth Int. Workshop Genet. Host-Parasite Interactions in Forestry: Disease and Insect Resistance in Forest Trees. R. A. Sniezko, A. D. Yanchuk, J. T. Kliejunas, K. M. Palmieri, J. M. Alexander, and S. J. Frankel, tech. coords. Gen. Tech. Rep. PSW-GTR-240. U.S. Dep. Agric. For. Serv., Pacific Southwest Research Station, Albany, CA, U.S.A.

Rhoades, C. C., Brosi, S. L., Dattilo, A. J., and Vincelli, P. 2003. Effect of soil compaction and moisture on incidence of Phytophthora root rot on American chestnut (Castanea dentata) seedlings. For. Ecol. Manage. 184:47-54

Ristaino, J. B., and Gumpertz, M. L. 2000. New frontiers in the study of dispersal and spatial analysis of epidemics caused by species in the genus Phytophthora. Annu. Rev. Phytopathol. 38:541-576.

Roiger, D. J., and Jeffers, S. N. 1991. Evaluation of Trichoderma spp. for biological control of Phytophthora crown and root rot of apple seedlings. Phytopathology 81:910-917.

Rutter, P. A. 1990. Chestnut Pollinator's Guide. Badgersett Research Corporation Bulletins. http://www.badgersett.com/sites/default/files/info/publications/ Bulletin1v1_0.pdf

Santos, C., Nelson, C. D., Zhebentyayeva, T., Machado, H., Gomes-Laranio, J. and Costa, R. L. 2017. First interspecific genetic linkage map for Castanea sativa $\times$ Castanea crenata revealed QTLs for resistance to Phytophthora cinnamomi. PLoS One 12:e0184381.

Sharpe, S. 2017. Phytophthora species Associated with American, Chinese, and Backcross Hybrid Chestnut Seedlings in Field Sites in the Southeastern United States. M.S. thesis, Clemson University, Clemson, SC, U.S.A.

Steiner, K. C., Westbrook, J. W., Hebard, F. V., Georgi, L. L., Powell, W. A., and Fitzsimmons, S. F. 2017. Rescue of American chestnut with extraspecific genes following its destruction by a naturalized pathogen. New For. 48:317-336

Tucker, C. M. 1933. The Distribution of the Genus Phytophthora. Res. Bull Univ. Mo. Agric. Exp. Stn. no. 0184. University of Missouri Agricultural Experimental Station, Columbia, MO. https://mospace.umsystem.edu/xmlui/ handle/10355/53375 
Westbrook, J. W. 2018a. Merging backcross breeding and transgenic blight resistance to accelerate restoration of the American chestnut: The American Chestnut Foundation's breeding and selection plan 2015-2025. The American Chestnut Foundation. https://www.acf.org/wp-content/uploads/2018/03/TACF_ 2015-2025_BreedingSciencePlan_updated2_9_18.pdf

Westbrook, J. W. 2018b. A plan to diversify transgenic blight-tolerant American chestnut populations. J. Am. Chestnut Found. 32:31-36.

Wickham, H. 2009. ggplot2: Elegant Graphics for Data Analysis. Springer-Verlag, New York, NY, U.S.A.
Zentmyer, G. A. 1980. Phytophthora cinnamomi and the Diseases it Causes. Monogr. No. 10. The American Phytopathological Society, St. Paul, MN, U.S.A. Zentmyer, G. A. 1988. Origin and distribution of four species of Phytophthora. Trans. Br. Mycol. Soc. 91:367-378.

Zhang, B., Oakes, A. D., Newhouse, A. E., Baier, K. A., Maynard, C. A., and Powell, W. A. 2013. A threshold level of oxalate oxidase transgene expression reduces Cryphonectria parasitica-induced necrosis in a transgenic American chestnut (Castanea dentata) leaf bioassay. Transgenic Res. 22: 973-982. 